\title{
Climatic, Environmental and Oceanographic Changes Over the Past MillenNiUM, RECONSTRUCTED FROM A PALYNOLOGICAL RECORD OF THE INNER URUgUAYAN CONTINENTAL SHELF
}

\section{Dominique Mourelle ${ }^{1 *}$, Laura Perez ${ }^{1}$, Till Jens Jörg Hanebuth ${ }^{2}$, Hendrik Lantzsch ${ }^{3}$ and Felipe GARCÍA-RODRÍGUEZ ${ }^{1,4}$}

1 Centro Universitario Regional del Este, CURE-Rocha, Uruguay

2 Department of Coastal and Marine Systems Sciences, Coastal Carolina University, U.S.A.

3 MARUM - Center for Marine Environmental Sciences and Faculty of Geosciences, University of Bremen, Leobener Straße, 28359 Bremen, Germany

4 Universidade Federal do Rio Grande, Instituto de Oceanografia, Programa de Pós-Graduação em Oceanografia Física, Química e Geológica, Rio Grande, Brazil

* Corresponding author, domodica@gmail.com

Received on 21 September 2018

Received in revised form on 17 December 2018

Accepted on 18 December 2018

Editor: Leticia Burone, Universidad de la República, Uruguai
Citation:

Mourelle, D., Perez, L., Hanebuth, T.J.J., Lantzsch, H., García-Rodríguez, F., 2018. Climatic, environmental and oceanographic changes over the past millennium, reconstructed from a palynological record on the inner Uruguayan continental shelf. Journal of Sedimentary Environments, 3 (4): 234-252.

\section{Abstract}

In order to strengthen and update knowledge on climatic, environmental and oceanographic changes on the inner Uruguayan continental shelf, we studied pollen, dinocyst and other non-pollen palynomorph assemblages on the sediment core GeoB13813-4. This core was taken from the Rio de la Plata (RdlP) mud depocenter and its remarkable high sedimentation rate for the last ca. $1000 \mathrm{cal}$ yr BP reflects the high terrigenous supply from RdlP. Most pollen and spores are originated from the RdlP grasslands, the vegetation that covers the lower reaches of the La Plata Drainage Basin (LPDB). They mainly represent the regionally dominant grasslands, but also the riparian forests, Butia yatay palm populations, and the herbaceous-bushy marshes around the mouth of the estuary. Pollen from salt marshes, Atlantic rainforest, and Araucaria forests located in southern Brazil reached the study site, probably transported by coastal ocean currents, whereas pollen from Andean regions would represent a long-distance transport by wind. Changes in both proportion and concentration of freshwater and marine

\section{Introduction}

Palaeoceanographic records derived from marine sediment cores taken at a mud belt, located on the inner shelf of the southwestern Atlantic Ocean, provide an exceptional sedimentary record to reconstruct climatic and environmental changes during the Late Holocene (Anderson, 2007; Lantzsch et al., 2014; Perez et al., 2016). In particular, pollen analyses significantly contribute to the

palynomorphs indicate variability in freshwater input to the inner Uruguayan shelf. From ca. 1000 to 230 cal yr BP, significant marine influence of Subtropical Shelf Waters (STSW) was inferred, which was diluted by the freshwater supply from the Uruguayan mainland. This time interval was interrupted between ca. 690 to $575 \mathrm{cal} \mathrm{yr}$ BP by an increased freshwater contribution to the study area under the influence of Subantarctic Shelf Waters (SASW). From ca. 230 to $25 \mathrm{cal}$ yr BP, a strong influence of RdlP waters was detected, only followed by another phase of dominant STSW during the past century. Such changes were related to regional climatic variability, i.e., Medieval Climate Anomaly, Little Ice Age and Current Warm Period. After ca. 1960 AD, the anthropogenic impact within the LPDB was clearly evidenced both by eutrophication and the first occurrence of PINUS pollen.

Keywords: Palynology. Dinocysts. Diatoms. Southeastern South America. Southwestern Atlantic Ocean. Past climate.

knowledge of past vegetational and climatic changes over the South American continent because they capture the variability derived from an interaction between a large river system (discharge as a result of precipitation) and an oceanic frontal zone on the continental shelf (location as a result of the regional wind regime; Mourelle et al, 2015a; Gu et al., 2017). Studies of marine depositional successions also allow for a direct correlation of marine and terrestrial signals as 
combined indicators of paleoenvironmental changes (Behling et al., 2002). Palynomorphs deposited in marine sediment may include both autochthonous (i.e., dinocysts) and allochthonous elements having originated from terrestrial vegetation (pollen grains, spores) and freshwater biota (algae, cyanobacteria). The allochthonous components also reflect long-distance transport by winds, fluvial discharge and ocean currents (Vernal, 2009). In addition, allochthonous elements can provide detailed information on the vegetation cover, but this requires a careful interpretation of marine pollen diagrams because of the complex transport pattern and sedimentation processes in the coastal ocean, which may lead to a strong potential bias of the results (Dupont, 1999). Palynological studies from marine successions collected from the inner continental shelf thus allow for paleoenvironmental reconstructions at local and regional scales.

Until today, palynological analyses in the campos region of the RdlP grasslands, the main complex of extended grassland ecosystems in South America $\left(750,000 \mathrm{~km}^{2}, 28^{\circ}-38^{\circ} \mathrm{S}\right.$; Soriano, 1991; Dixon et al., 2014) (Fig. 1A), have been used for paleolimnological reconstructions. Such studies suggested that grasslands were dominant in the whole region during the Late Holocene, while locally in the surroundings of the water bodies, the vegetation would have been diverse, consisting of freshwater marshes and riparian forests, under wet climatic conditions (Behling et al., 2005; Iriarte, 2006; García-Rodríguez et al., 2010; Mourelle et al., 2015a, b; 2017, 2018). This observation is consistent with the conditions inferred from the analysis of other paleo-environmental proxies, which inferred temperate to warm and humid conditions for the last 2000 cal yr BP (Iriarte, 2006; del Puerto, 2009). However, concomitant pulses of climatic amelioration and deterioration caused changes in the structure, composition and extension of plant communities (del Puerto, 2009). In particular, for southern Uruguay, the occurrence of both a warmer and more humid pulse during the Medieval Climatic Anomaly (MCA, 900-1250 AD), and a drier and colder pulse during the Little Ice Age (LIA, 14001850 AD) were suggested (del Puerto et al., 2013). Palynological analyses from the campos region do not reflect such climatic variability, possibly due to the low temporal resolution of the Late Holocene depositional successions.

Multi-proxy records performed on marine gravity cores have been studied to reconstruct vegetation, climate, and ocean dynamics in southern Brazil and the adjacent South Atlantic for the last 73.5 kyr (e.g., Razik et al., 2013; Gu et al., 2017, 2018b). These records were characterized by low temporal resolution for the Late Holocene. However, the inner continental shelf off the Uruguayan coast is characterized by an elongated seafloor depression, which represents the pre-Holocene surface of the ancient fluvial valley of the RdlP (RdlP paleo-valley; RPPV) (Cavallotto and Violante, 2005; Lantzsch et al., 2014). The RPPV extends from the Paraná River to Rio Grande do Sul (Brazil), carved under sub-aerial conditions during the last pre-Holocene regression, and then filled up during the last sea-level rise (Cavallotto, 2002; Cavallotto and Violante, 2005; Lantzsch et al., 2014). Sediment core GeoB13813-4 was taken from such sediments, containing a $10-\mathrm{m}$ long record that encompasses the past millennium (Lantzsch et al., 2014) and therefore yields a high-resolution archive for a detailed and continuous paleoecologically reconstruction. In this sense, Perez et al. (2016, 2017, 2018) studied the diatom flora, conventional geochemical (C, N, and their isotopes), XRF element ratios (Ca, Ti, $\mathrm{Al}, \mathrm{Fe}$, and $\mathrm{K}$ ) and biogenic silica (BSi) on core GeoB13813-4 to decipher the history of terrigenous sediment input from the RdlP system. In this study, we analyze the palynological content with in the same core in order to (1) determine how palynological assemblages changed in relation to the continental sediment supply, (2) evaluate the paleobotanical potential of this succession with regard to the different types of vegetation that proliferate in southeastern South America, and (3) integrate our results into a multi-proxy approach by comparing pollen to other paleoceanographic and paleolimnological records from the southeastern South America for the last $1000 \mathrm{cal}$ yr BP in order to strengthen and update knowledge on climatic, environmental and oceanographic changes.

\section{Study Area}

\subsection{Hydrology and bydrograpby}

The continental margin off southeastern South America is characterized by both high sediment supply from the RdlP, as well as the confluence of two important oceanographic currents (Möller et al., 2008; Palma et al., 2008; Lantzsch et al., 2014) (Fig. 1). The RdlP constitutes the lower reach of LPDB, the second largest river system in South America, draining an area of approximately $3.1 \times 10^{6}$ $\mathrm{km}^{2}$, which represents about $20 \%$ of the South American continent (Acha et al., 2008) (Fig. 1). The RdlP is formed by the confluence of the Paraná and Uruguay rivers, and discharges an average of 23,000 $\mathrm{m}^{3} \mathrm{~s}^{-1}$ of freshwater and a

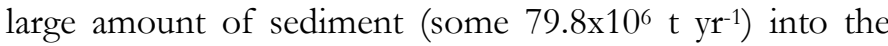
southwestern Atlantic Ocean (Depetris et al., 2003; Piola et al., 2008; Krastel et al., 2012; Razik et al., 2013; Lantzsch et al., 2014). The Paraná River supplies 79\% of this discharge, and the Uruguay River contributes the remaining $21 \%$ (Pasquini and Depetris, 2007). Most of this discharge forms the low-salinity Plata Plume Water (PPW) that is spreads out over the inner Uruguayan and Brazilian continental shelf (Palma et al., 2008; Piola et al., 2008) (Fig. 1).

The inner continental shelf is overflown by the Subtropical Shelf Front (STSF) that forms a thermohaline boundary between the northward-flowing, cold and less saline SASW and the southward-directed warm and salty STSW (Möller et al., 2008; Piola et al., 2008) (Fig. 1). 
A)

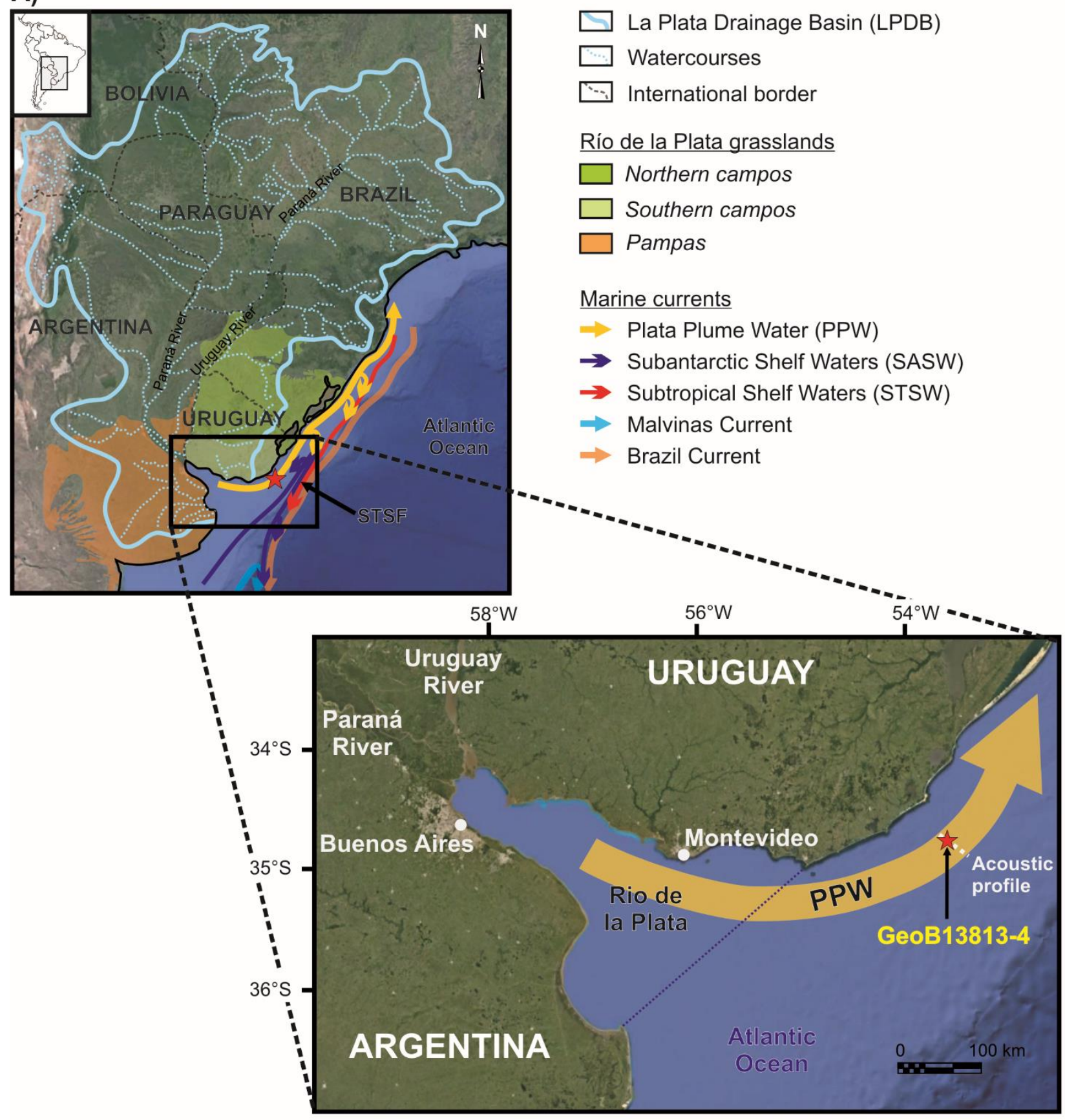

B)

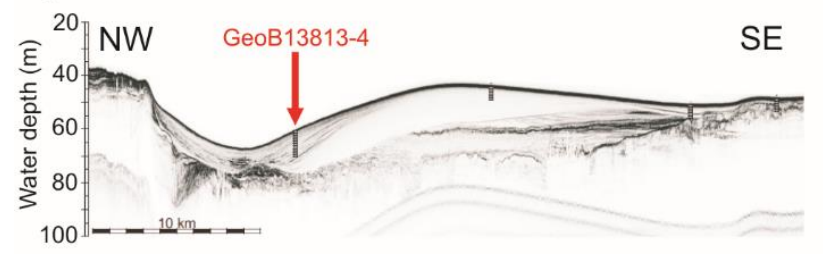

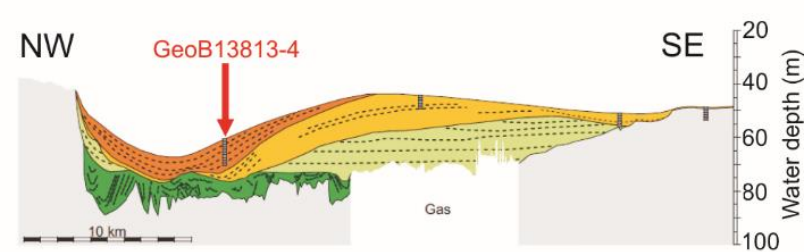

Acustic profile - stratigraphic units
U1
U2
U3
U4

Fig. 1. A) Map of the study area: La Plata Drainage Basin, Rio de la Plata grasslands, and shelf water masses of the southwestern Atlantic Ocean. STSF: Subtropical Shelf Front. Inlet map: location of seismo-acoustic profile and core GeoB13813-4. Maps modified from Piola et al. $(2005,2008)$ and Lantzsch et al. (2014). B) Seismo-acoustic $4 \mathrm{kHz}$ (PARASOUND) profile and interpreted inner-shelf architecture, with GeoB13813-4 core position, modified from Lantzsch et al. (2014). 
The STSF is suggested to be the shelf-ward shallowwater continuation of the Brazil-Malvinas Confluence Zone, where the cold and less salty northward-flowing Malvinas Current collides with the warm, salty southward-flowing Brazil Current (Piola et al., 2000; Palma et al., 2008; Lantzsch et al., 2014) (Fig. 1).

\subsection{Inner-shelf architecture and stratigraphic units}

The inner continental shelf off the Uruguayan coast is characterized by an elongated seafloor depression that is located $40 \mathrm{~km}$ off the coast (Lantzsch et al., 2014). This depression represents the pre-Holocene surface of the ancient fluvial valley of the RdlP, that was about $35 \mathrm{~km}$ wide and up to $50 \mathrm{~m}$ deep before it became partly filled by Holocene sediments during the last sea-level rise (Cavallotto and Violante, 2005; Lantzsch et al., 2014). Above this depression, four stratigraphic units (U1-U4) have been defined according to their sedimentary characteristics, bounding unconformities and their acoustic facies (Lantzsch et al., 2014) (Fig. 1). U4 truncates into older strata (although of uncertain age). Channels were filled during sea-level rise and preceded the formation of $\mathrm{U} 3$, which sedimentary characteristics indicate a tidal origin under estuarine conditions. U2 represents a local inner-self sand depocenter that formed at ca. $4600 \mathrm{cal}$ yr BP, when sea level was approximately $+3 \mathrm{~m}$ higher than present level (Prieto et al., 2017), and therefore developed under full-marine conditions. U1 sediment accumulation started around 1000 cal yr BP, and represents a relatively modern shelf mud depocenter above the observed RPPV (Lantzsch et al., 2014).

\subsection{Climate}

Regional atmospheric circulation is under the influence of the South American Monsoon System (SAMS) and the South Atlantic semi-permanent high-pressure cell (Vera et al., 2006; Razik et al., 2013). Both systems are responsible for the transport of considerable moisture over the eastern LPDB, and hence, for the seasonal precipitation peak of the austral summer, when the Intertropical Convergence Zone (ITCZ) migrates southwards (Vera et al., 2006; Garreaud et al., 2009; Razik et al., 2013). During the austral winter, the Southern Westerly Wind Belt (SWWB) extends northwards to $\sim 30^{\circ} \mathrm{S}$ promoted by the northerly position of ITCZ. As a consequence, the anticyclones gather moisture from local air masses and generate precipitation along the eastern LPDB by creating tropospheric instabilities associated with persistent polar fronts (Garreaud et al., 2009; Razik et al., 2013).

The regional climatic system exhibits an interannual and interdecadal variability, associated to environmental changes related to the El Niño-Southern Oscillation (ENSO) and the Pacific Decadal Oscillation (PDO), respectively (Depetris and Pasquini, 2007; Garreaud et al., 2009; Barreiro, 2010). It has been suggested that during both the warm El Niño and the positive PDO phases, there is an increasing trend in
RESEARCH PAPER

precipitations over the LPDB associated with an intensification of SAMS, which leads to a higher river discharge (Depetris and Pasquini, 2007; Garreaud et al., 2009; Barreiro, 2010; García-Rodríguez et al., 2014). At multidecadal timescales, the Atlantic Mutidecadal Oscillation (AMO) seems to reduce SAMS intensity in its positive phase (Chiessi et al., 2009). The opposite trend has been observed for negative ENSO, PDO and AMO phases.

The northward penetration of PPW along the Brazilian coast is primarily controlled by the intensity of southerly winds and secondarily by continental run-off. This northward expansion occurs predominantly during the austral winter (Piola et al., 2000, 2005). As a consequence, PPW drifts from $28^{\circ} \mathrm{S}$ during the austral winter to approximately $38^{\circ} \mathrm{S}$ during the summer, when northeasterly winds force a southeastward retreat of the PPW, spreading low-salinity waters over the entire continental shelf off the RdlP (Guerrero et al., 1997; Piola et al., 2000; Palma et al., 2008).

\subsection{Vegetation}

The lower reaches of LPDB flow through the RdIP grasslands, divided by León (1991) into the pampas, in the eastern Argentina, and the campos, in Uruguay and southern Rio Grande do Sul in Brazil (Fig. 1A). The campos region displays a noticeable biodiversity, with ca. 3000 species of vascular plants, including more than 550 different grass species from very diverse genera, such as Paspalum, Nassella and Aristida (Andrade et al., 2018). The presence of woody species gradually diminishes from north to south, many of them reaching their southern distribution boundary in campos region, hence being absent in the pampas.

Natural grasslands represent the predominant vegetation type in the campos region and are extended all over Uruguay (ca. $65 \%$ of the territory), in flat and gently-rolling relief, hills, gentle hills and low mountains (Lezama et al., 2011; MGAP-DIEA, 2011). Woody vegetation covers approximately $4.3 \%$ of the territory (Petraglia and Dell'Acqua, 2006), and consists of about 300 species of trees and shrubs (Brussa and Grela, 2007). They proliferate constrained to certain topographic features with relatively high-water availability or wind protection. Further information about the different vegetation types that develop in the campos region can be found elsewhere (Mourelle and Prieto, 2012, 2016).

Along the margin of rivers and water streams, riparian forests develop, dominated by tree species that are spatially arranged according to their water requirements. Hydrophilous trees develop in the floodplains, while mesophilous vegetation develops in areas of reduced water availability. Some exclusive hydrophilous taxa are SALIX CHILENSIS, PHYLLANTHUS SELLOWLANUS, CEPHALANTHUS GLABRATUS and SEBASTLANLA COMMERSONLANA, whereas some mesophilous ones are SCUTIA BUXIFOLIA, CELTIS EHRENBERGIANA, LITHRAEA 
MOLLEOIDES, SCHINUS LONGIFOLIUS and many MYRTACEAE (e.g., BLEPHAROCALYX SALICIFOLIUS, MYRCEUGENLA GLAUCESCENS, MYRCIANTHES CISPLATENSIS) and Primulaceae (e.g., MYRSINE CORIACEA, MYRSINE FERRUGINEA) (Brussa and Grela, 2007). Humid riparian forests understory promotes the development of pteridophytes. Butia yatay palm grows interspersed among the dominant grasslands in Entre Ríos, Corrientes and Santa Fe provinces in Argentina, Uruguay and Rio Grande do Sul, Brazil (Geymonat and Rocha, 2009). They are considered as part of a relict community developed over sandy soils (Patterer et al., 2017).

In particular, the presence of tropical vegetation along the Uruguay River leads to a much higher biodiversity in comparison to other minor rivers in the region. Similarly, the floristic contributions from the Paraná River generate a particularly high diversity on the southwestern Uruguayan coast (Brussa and Grela, 2007). Eastwards, salt marshes develop in intertidal coastal areas and topographic depressions that get seasonally inundated by marine water of the Atlantic Ocean. They are dominated by Spartina (Poaceae), Sarocornia (Chenopodioideae), Scippus (Cyperaceae) and Juncus (Juncaceae), all halophilous taxa (Isacch et al., 2006).

The vegetation of the Paraná River floodplain is a mosaic of vegetation assemblages, where in addition to riparian forests, herbaceous-bushy marshy vegetation with species tolerant to various degrees and frequencies of flooding develop. Marshy-herbaceous vegetation contains aquatic grasses (Panicum elephantipes), rooted floating species (Ludwigia peploides), and rooted species (POLYGONUM PUNCTATUM), while the bushy species consist of Solanum glaucophyllum, Sesbania virgata, Mimosa pigra and Baccharis salicifolia (Marchetti et al., 2013). In addition, different assemblages of aquatic vegetation are related to the characteristics of the floodplain water bodies, where rooted aquatic species such as Myriophyllum aquaticum, Enydra anagallis and Hydrocotyle bonariensis appear among the most frequent species. Other frequent species are free floating Eichhornia spp., Azolla filiculoides, Limnobium laevigatum, rooted floating NYMPHOIDES INDICA, POLYGONUM FERRUGINEUM and PASPALUM REPENS (Marchetti et al., 2013).

After the European colonization, the campos region has progressively become one of the most important areas of livestock and grain production in the world (Bilenca and Miñarro, 2004). Furthermore, the expansion of cropland areas, the introduction of exotic grass species and their associated weeds, and more recently the substitution of grasslands for exotic forest plantations, mainly by Eucalyptus spp. and PINUS spp., deeply modified the original landscape (Paruelo et al., 2004; Panario and Gutiérrez, 2007).

\section{Materials and Methods}

\subsection{Sampling and sediment analyses}

A $1028 \mathrm{~cm}$ long sediment core (GeoB13813-4; $\left.34^{\circ} 44.22^{\prime} \mathrm{S}, \quad 53^{\circ} 33.27^{\prime} \mathrm{W}\right)$ was taken from the mud depocenter (57 $\mathrm{m}$ water depth) using a gravity corer during research cruise M78/3a with the German research vessel METEOR on May 2009 (Fig. 1). During this expedition, 4 $\mathrm{kHz}$ sediment-acoustic data were collected with the Parasound P70 sub-bottom profiling and bathymetric survey system aboard RV Meteor (Krastel et al., 2012). Detailed information about the acoustic profiles from the Uruguayan shelf has been published by Lantzsch et al. (2014).

Sub-samples for pollen, spores, organic-walled dinoflagellate cysts (dinocysts) and other non-pollen palynomorphs (NPPs) were analyzed. In addition, further samples from the bottom of the core were analyzed for diatoms, in order to expand the diatomological study of Perez et al. (2017).

\subsection{Stratigraphy and Chronology}

The chronology of core GeoB13813-4 is based on six radiocarbon dates, determined on bivalve shell samples that were distributed evenly over the core and preserved in life position (Table 1) (Perez et al., 2016).

Radiocarbon dates were calibrated against the Marine13 calibration curve (Reimer et al., 2013). For reservoir correction, the conventional age of $324 \pm 30$ years determined by Alves et al. (2016) was applied. Age-depth model was constructed by the Bayesian age-depth modelling approach using the program "Bacon" (Blaauw and Christen, 2011).

\subsection{Palynological analysis}

Standard techniques were performed for palynological extraction using $\mathrm{KOH}, \mathrm{HCl}$, and $\mathrm{HF}$ (Fægri and Iversen, 1989). Acetolysis process was not applied to avoid the damage of dinocysts. Two Lycopodium clavatum spore tablets were added before treatment to calculate palynomorph concentration (Stockmarr, 1971).

Due to the low pollen concentration, at least 100 pollen grains were counted for all samples. Pollen grains and spores were considered as originated from the terrestrial vegetation and therefore represent the "continental" component to the palynomorph assemblage. Their proportions were calculated as the percentage of the total pollen sum plus spores sum. Algae and cyanobacteria represent the freshwater continental input, referred to as the "freshwater" component; whereas dinocysts, foraminifera and acritarchs represent the "marine" component to the palynomorph assemblage. Algae, cyanobacteria, dinocysts, foraminifera and acritarchs were calculated as the percentage of the total palynomorphs sum. The presence of Azolla filiculoides was inferred from the presence of their spores, glochids or massulae.

Pollen and spores were identified using atlases and published keys (e.g., Bauermann et al., 2013; Mourelle and Prieto, 2016), and the modern reference collection at the CURE-Rocha, Uruguay. Identification of dinocysts and 
NPPs was based on van Geel (2001), Borel et al. (2003), Borel (2007) and Zonneveld et al. (2013). Vascular plant nomenclature follows the system of the Missouri Botanical Garden (http://www.tropicos.org/). Since there are significant differences between the concepts of "plant taxa" and "palynomorphological types" and in order to provide the necessary nomenclatural clarity as well, names of pollen and spores are presented in SMALL CAPITALS in figures and refrain from using italics (de Klerk and Joosten, 2007).

Results are presented as percentage and concentration palynomorph diagrams. All identified palynomorphs were considered to calculate the percentages and for numerical analysis. Palynomorph zones ( $\mathrm{PalZ}$ ) were determined by a CONISS stratigraphically constrained cluster analysis, and diagrams were drawn using the TGView 2.0.4 program (Grimm, 2004).

\subsection{Diatom analysis}

Diatom samples were treated with $\mathrm{Na}_{2} \mathrm{P}_{2} \mathrm{O}_{7}, 35 \%, \mathrm{HCl}$ and $30 \% \mathrm{H}_{2} \mathrm{O}_{2}$ (Metzeltin and García-Rodríguez, 2003). A minimum of 400 valves was counted in each sample. Diatom species were identified and separated into groups according to their ecological salinity preference, i.e., freshwater, marine and marine-brackish, following the standard diatom literature (e.g., Hasle and Syvertsen, 1996; Witkowski et al., 2000; Metzeltin and García-Rodríguez, 2003; Metzeltin et al., 2005; Hassan et al., 2009; Sar et al., 2010).

Tab. 1. Radiocarbon dates from GeoB13813-4 core (Perez et al., 2016). Poz = Poznań Radiocarbon Laboratory (Poland).

\begin{tabular}{|l|c|c|c|c|}
\hline Code (Poz-) & $\begin{array}{c}\text { Depth } \\
\text { (cm) }\end{array}$ & ${ }^{\mathbf{1 4}} \mathbf{C} \mathbf{y r}$ BP & $\begin{array}{c}\text { Bacon weighted average age } \\
\text { (cal yr BP) }\end{array}$ & $\begin{array}{c}\text { Sedimentation rate } \\
\left(\mathbf{c m ~ y r}^{-1} \mathbf{)}\right.\end{array}$ \\
\hline $\mathbf{3 5 1 9 8}$ & 255 & $640 \pm 30$ & 136 & 1.3 \\
\hline $\mathbf{4 7 9 3 5}$ & 305 & $775 \pm 35$ & 180 & 1.1 \\
\hline $\mathbf{4 2 4 2 8}$ & 447 & $1000 \pm 40$ & 317 & 1.0 \\
\hline $\mathbf{3 5 1 9 9}$ & 560 & $1090 \pm 30$ & 424 & 1.1 \\
\hline $\mathbf{4 7 9 3 7}$ & 705 & $1220 \pm 40$ & 570 & 1.0 \\
\hline $\mathbf{4 2 4 2 9}$ & 964 & $1600 \pm 30$ & 908 & 0.8 \\
\hline
\end{tabular}

Results are presented in summarized diatoms percentage diagram, as the complete analysis has been published elsewhere (Perez et al., 2017). Taxa of indicative of warm waters were grouped (referred hereafter to as WW diatoms): Thallassiosira oestrupii, Thallasionema pseudonitzschoides, Trigonium reticulum, Trigonium alternans and Cymatotheca weissflogii. Diatom zones (DZ) were determined by using the CONISS stratigraphically constrained cluster analysis performed using all identified diatoms, and diagrams were drawn using the TGView 2.0.4 program (Grimm, 2004). Biogenic silica (BSi) analysis detailed in Perez et al. (2018) was used as indicative of diatom concentration changes relative to the $405 \mathrm{~cm}$ diatom concentration.

\section{Results}

\subsection{Stratigraphy and chronology}

The $4 \mathrm{kHz}$ seismo-acoustic profiles reveal that the sedimentary succession of core GeoB13813-4 exclusively covers unit U1 (Fig. 1) (Lantzsch et al., 2014). It predominantly consists of gray mud with scattered shells throughout. Gray sandy mud is present between 520 and 260 $\mathrm{cm}$ depth, and in the upper most $130 \mathrm{~cm}$ (Fig. 2) (Krastel et al., 2012). The sediment core record spans the last $1000 \mathrm{cal}$ yr BP. Radiocarbon dates and sediment stratigraphy indicate continuous sedimentation at an average rate of $1.1 \mathrm{~cm} \mathrm{yr}^{-1}$ (Table 1; Fig. 3).

\subsection{Palynological analysis}

Pollen and spores contents of core GeoB13813-4 are characterized by herbs dominance (15-50\%), mainly POACEAE, ASTERACEAE, CYPERACEAE and CHENOPODIOIDEAE (Figs. 4, 5). Despite woody pollen taxa were present throughout the sequence $(<10 \%)$, each pollen type has a scattered distribution. They were represented by both mesophilous (MYRTACEAE, CELTIS, MYRSINE, LITHRAEA/SCHINUS, RHAMNACEAE and ALLOPHYLUS EDULIS) and hydrophilous (SALIX CHILENSIS, PHYLLANTHUS SELLOWIANUS, SEBASTIANIA/ACANTHOSYRIS and CEPHALANTHUS GLABRATHUS) taxa. Woody pollen from plants not described for the RdlP grasslands was also found, such as PODOCARPUS, ALNUS and NOTHOFAGUS, as well as PINUS from alien plants were registered in the uppermost part. Aquatic herbs reached up to $3 \%$ and were mainly represented by emergent taxa (e.g., POLYGONUM, APIACEAE, TYPHA and ECHINODORUS). Submerged MYRIOPHYLLUM and floating AZOLLA were also present. Spores were represented by Bryophytes $(<3 \%)$ and Pteridophytes $(<5 \%)$. Such palynomorphs represent the "continental" component to the palynomorph assemblage of the sediment core (20-55\%).

NPPs include algae (Botryococcus and Pediastrum) and cyanobacteria (Gloeotrichia) and represent the "freshwater" component to the palynomorph assemblage, whose 
proportion did not significantly change over time $(<5 \%)$. Dinocysts included Operculodinium centrocarpum and Spinifertites spp., and acritarchs encompassed Michrystridium and Cymatiosphaera. Dinocysts and acritarchs, together with foraminifera, represent the "marine" component (45-85\%). Such marine palynomorph proportions and concentrations were variable throughout the sequence (Figs. 4, 5).

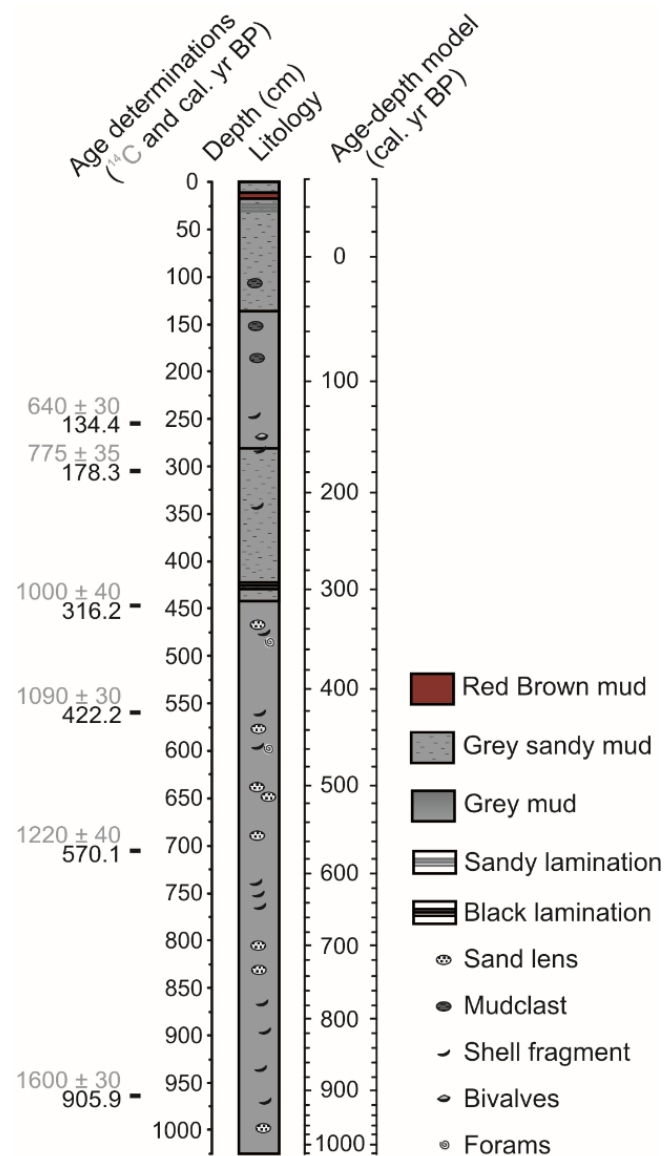

Fig. 2. Sediment description (modified from Krastel et al., 2012) and radiocarbon dates from GeoB13813-4 core, plotted against depth, and calibrated age scale (see Fig. 3).

CONISS cluster analysis applied to all identified palynomorphs allowed to define the following three palynological zones (PalZ; Figs. 4,5).

PalZ-I (1028 - $360 \mathrm{~cm})$ : marine palynomorph proportion fluctuated around 65\% (45-85\%), characterized by the dominance of dinocyst assemblage, mainly represented by $O$. centrocarpum (35-75\%), accompanied by acritarchs $(<15 \%)$ and foraminiferal linings $(<5 \%)$. The marine palynomorphs showed highest concentration, with fluctuations and several peaks $>60,000$ palynomorphs $/ \mathrm{cm}^{3}$. Continental palynomorph concentration showed values around 20,000 palynomorphs $/ \mathrm{cm}^{3}$ (but reaching values higher than 30,000 palynomorphs $/ \mathrm{cm}^{3}$ ), while freshwater forms mainly fluctuated around 500 palynomorphs $/ \mathrm{cm}^{3}$, reaching values up to 1700 palynomorphs $\left./ \mathrm{cm}^{3}\right)$.

PalZ-II (360 - $120 \mathrm{~cm}$ ): palynological assemblage shifted toward a continental and marine co-dominance, both in terms of proportions and as in their concentration. Marine palynomorphs fluctuated around 60\% (50-70\%), still characterized by the dominance of dinocysts, but a decrease towards the upper section is observed, while the acritarch abundance increased up to $20 \%$. Continental and freshwater palynomorph concentrations exhibited very similar values, whereas marine palynomorph concentrations sharply decreased, showing values lower than 20,000 palynomorphs $/ \mathrm{cm}^{3}$.

PalZ-III (120 - $0 \mathrm{~cm})$ : dominance of marine palynomorphs was recorded, where dinocysts increased and acritarchs diminished in relation to the previous zone. In addition, marine palynomorphs showed a slight increase in their concentration, ranging from 20,000 to 30,000 palynomorph $/ \mathrm{cm}^{3}$. A subzone was visually established to accommodate distinctive changes: PalZ-IIIb $(65 \mathrm{~cm})$ showed lower dinocysts and higher acritarchs proportions than PalZ-IIIa (<65 and $>5 \%$, respectively). In addition, a slightly higher freshwater palynomorph concentration was detected (with peaks higher than 400 palynomorphs $/ \mathrm{cm}^{3}$ ), simultaneously with the first PINUS appearance in the pollen spectra (Fig. 4).

\subsection{Diatom analysis}

Figure 6 shows the summarized diatom percentage diagram. Tycoplanktonic marine taxa are mainly represented by Paralia sulcata, whereas the freshwater group is almost exclusively made up of many species of Aulacoseira spp. all over the sequence.

Five diatom zones were defined based on the CONISS cluster analysis. DZ-I $(1028-800 \mathrm{~cm})$ was dominated by marine diatoms (up to 85\%), mainly represented by tychoplanktonic and planktonic taxa. Freshwater diatoms displayed values up to $30 \%$. DZ-II $(800-710 \mathrm{~cm})$ registered a sharp increase in freshwater diatoms to values up to $45 \%$ (together with the concomitant decrease in marine diatoms). In DZ-III (710 - $300 \mathrm{~cm})$ marine diatoms dominated the assemblages again, reaching values up to $80 \%$, with a slight decreasing tendency towards the upper section (DZ-III a to DZ-IIIb; $530 \mathrm{~cm})$. In DZ-IV $(300-100 \mathrm{~cm})$, the freshwater diatoms dominated the assemblages with values up to $60 \%$. Finally, freshwater diatom values decreased, with a concomitant increase in marine forms and, for the first time, of the marine-brackish group. These changes were further accentuated from $65 \mathrm{~cm}$ depth to the top of the core, where marine and marine-brackish diatoms reached values up to $70 \%$ and $30 \%$, respectively.

Relatively high abundance of Chaetoceros spp. resting spores were observed throughout the sediment core $(\mathrm{min}=$ $0, \max =21.6$ and mean $=7.7 \%$, except for zones DZ-II, DZ-IIIb and DZ-IV (commonly of most up to 5\%; Fig. 6). Resting spores were positively correlated with the group of the WW diatoms $\left(\mathrm{r}^{2}=0.42, p<0.05\right)$, and they showed the same tendency described above, but at slightly higher values (up to $30 \%$ ). 

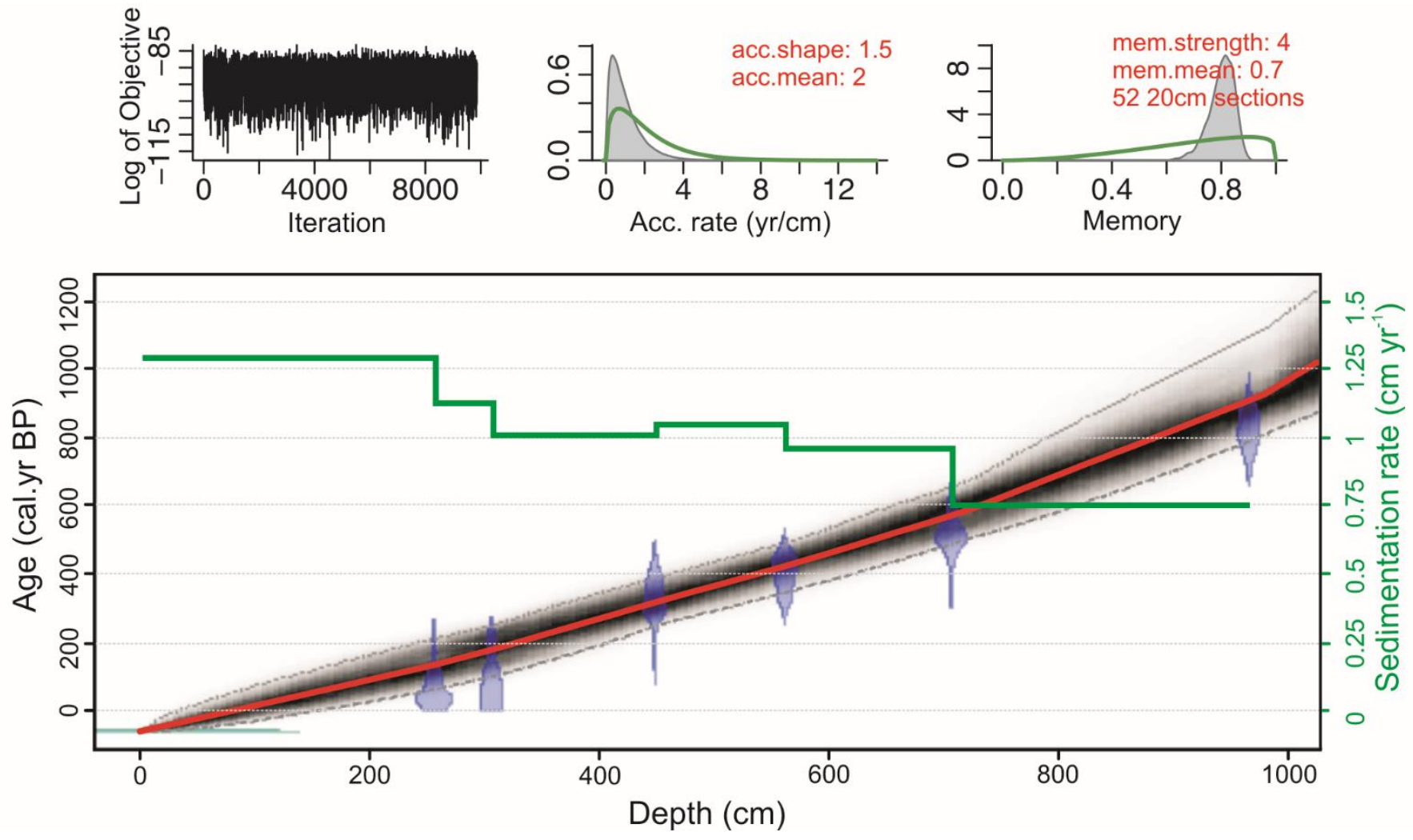

Fig. 3. Age-depth model for GeoB13813-4. Upper panels depict the Markov Chain Monte Carlo (MCMC) iterations (left); prior (green) and posterior (gray) distributions of accumulation rate (middle); and memory $\mathrm{R}$ (right). The bottom panel shows the age-depth model (gray), overlaying the calibrated distributions of the individual dates (blue); and sedimentation rates (green). Gray stripped lines indicate the age-depth model's 95\% probability intervals, and the red curve the "best" fit based in the weighted mean age for each depth.

\section{Discussion}

\subsection{Environmental background}

The mud depocenter on the inner Uruguayan continental shelf is characterized by homogeneous, predominantly muddy facies containing few shell fragments (Figs. 1B, 2). The transition from sand (U2) to mud (U1) deposition required a further weakening of the shelf current regime, most probably related to the southward shift of the STSF towards its modern position due to a stronger southward flow of the STSW, driven by more intense austral trade winds (Lantzsch et al., 2014; Razik et al., 2015). In addition, the beginning of unit $\mathrm{U} 1$ sediment accumulation should be connected to changes in LPDB, likely associated with the stabilization of the sea level (Prieto et al., 2017) and the onset of humid conditions in the Late Holocene (Behling, 2002; Behling et al., 2005; del Puerto et al., 2013; Mourelle et al., 2017), the latter having led to increasing RdIP discharge at about $2000 \mathrm{cal} \mathrm{yr} \mathrm{BP} \mathrm{(Mahiques} \mathrm{et} \mathrm{al.} \mathrm{2009;} \mathrm{del} \mathrm{Puerto} \mathrm{et} \mathrm{al.}$ 2013; Lantzsch et al. 2014). As a result of the increasing fluvial discharge and sediment transport, the Paraná delta formed at ca. $1700 \mathrm{cal} \mathrm{yr} \mathrm{BP} \mathrm{(Cavallotto} \mathrm{et} \mathrm{al.,} \mathrm{2004).}$

Sediment accumulation of unit U1 started around 1000 cal yr BP (Figs. 2, 3). Its remarkably high sedimentation rate reflects the strong and focused terrigenous supply by the RdlP. This agrees with Nd-isotope measurements on the sedimentary unit U1 that clearly identify the RdIP as the sole sediment source for the mud depocenter (Lantzsch et al., 2014).

\subsection{Continental vegetation}

Palynological assemblages deposited in the mud depocenter record consist of both allochthonous (pollen grains, spores, algae and cyanobacteria) and autochthonous (dinocysts, foraminifera and acritarchs) elements (Figs. 4, 5). No important changes were observed in pollen assemblages which could reflect stable plant communities at regional scale for the last $1000 \mathrm{cal} \mathrm{yr} \mathrm{BP,} \mathrm{in} \mathrm{agreement} \mathrm{with} \mathrm{other}$ studies from the campos region and adjacent areas (Behling, 2002; Vilanova and Prieto, 2012; Mourelle et al., 2018, and references therein). However, fluctuations in the palynomorph concentration and in freshwater algae and cyanobacteria abundances (Figs. 5, 6) suggest variability in the freshwater input to the inner Uruguayan continental shelf. This freshwater influence is supported by conventional geochemical ( $\mathrm{C}, \mathrm{N}$, and their isotopes), XRF element ratios $(\mathrm{Ca}, \mathrm{Ti}, \mathrm{Al}, \mathrm{Fe}$, and $\mathrm{K}$ ) and diatom proxy data (Perez et al., 2016, 2017).

Pollen assemblages indicate the dominance of grasslands in the landscapes, mainly by the major POACEAE and AsterACEAE values (Fig. 4). Nevertheless, POACEAE pollen 
probably comes also from the extensive floodplains of the Paraná River, where aquatic grasses such as Panicum elephantipes and Paspalum repens are very abundant, together with many CYPERACEAE and aquatic herbs, all of them also present in the pollen spectrum (e.g., CYPERACEAE, AZOLLA, POLYGONUM, MYRIOPHYLLUM and APIACEAE).

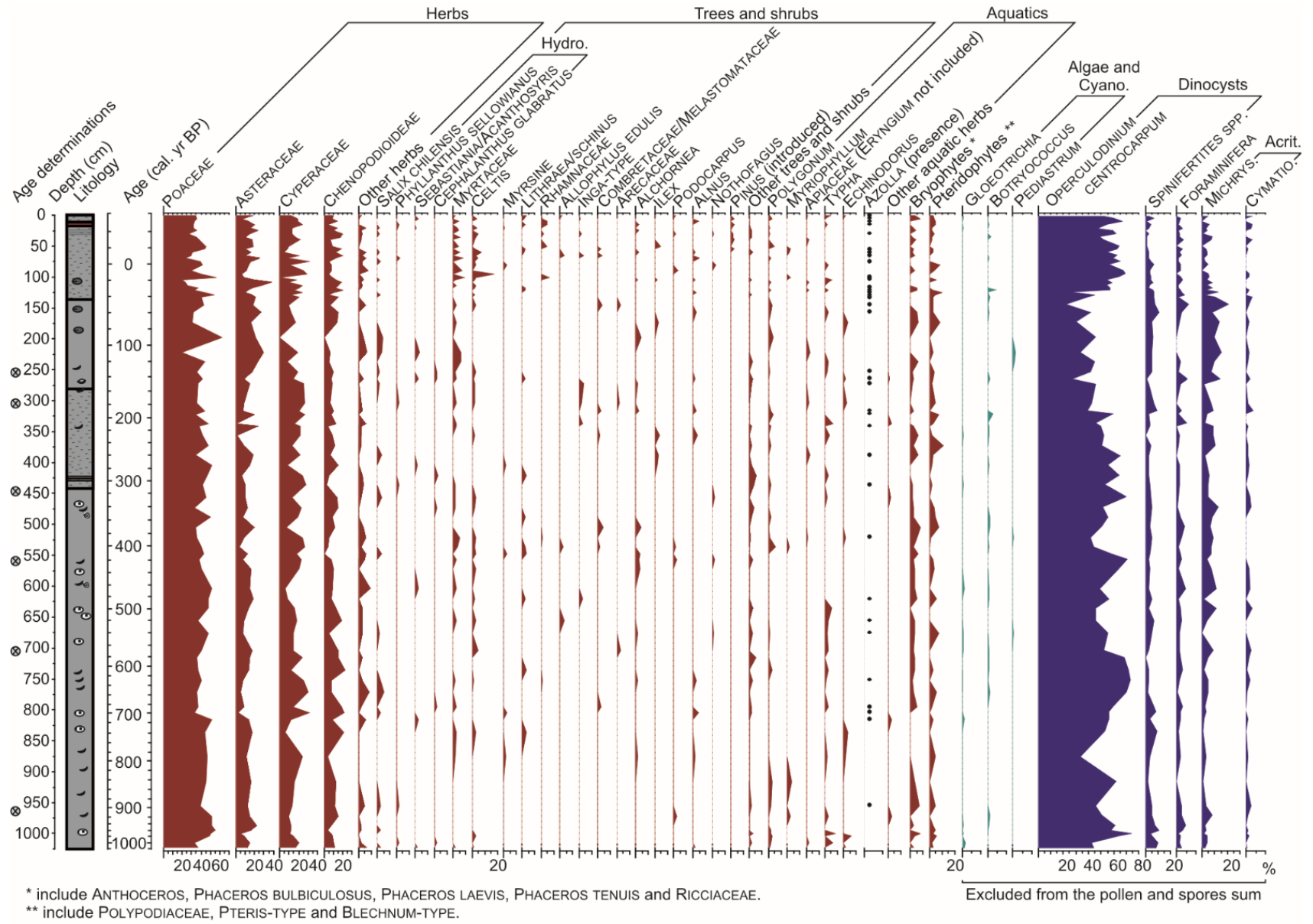

Fig. 4. Pollen, spores, dinocysts and NPPs percentage diagram for the main palynomorph types from GeoB13813-4 core. Hydro.: hydrophilous taxa; Cyano.: cyanobacteria; Michrys.: Michrystridium; Cymatio.: Cymatiosphaera; Acrit.: acritarchs.

Woody taxa from riparian forests in the campos region have mostly zoophilous pollination and they produce low quantities of poorly dispersed pollen grains (Mourelle and Prieto, 2016; Mourelle et al., 2017). As a consequence, the relatively low amount of woody pollen $(<5 \%$; Fig. 5) represents an important contribution into the mud depocenter, considering their very low concentration and its scattered presence throughout the sequence. Most of these pollen grains probably originated from riparian forest developed along the margins of the Paraná and Uruguay rivers, as suggested by the presence of hydrophilous SALIX CHILENSIS, PHYLLANTHUS SELLOWLANUS, SEBASTIANLA/ACANTHOSYRIS and CEPHALANTHUS GLABRATUS that exclusively develop in such forest types. Spores, mainly pteridophytes, are also frequent in modern riparian forest samples (Mourelle and Prieto, 2012), and are more easily transported by water over longer distances than pollen grains (Dai et al., 2014), which explains their important contribution to the analyzed assemblages. Woody pollen and spores transported via fluvial processes were already described for the northem RdIP coast (Mourelle et al., 2015a). More specifically, some woody pollen grains correspond to taxa that display their southern distribution boundary in the campos region of Rio Grande do Sul, such as ALCHORNEA TRIPLINERVIA, INGA VERA Or TERMINALIA AUSTRALIS (Sobral et al., 2006). INGA VERA and TERMINALLA AUSTRALIS are also observed southwards along the Uruguay River (Brussa and Grela, 2007). As a consequence, ALCHORNEA, INGATYPE and COMBRETACEAE/MELASTOMATACEAE pollen reach the study area through hydrodynamic processes from the Uruguay River discharge into the RdlP. Probably, ARECACEAE pollen also reach the study area by the same riverine route, originating from the Butia yatay palm populations that nowadays grow interspersed among grasslands on both river sides. Although ARECACEAE pollen is usually under-represented, surface samples from Butia yatay palm populations showed relatively high values of this type of pollen (ca. 7-8\%, Mourelle and Prieto, 2012; Muñoz, 2017). 
Palynomorph percentages

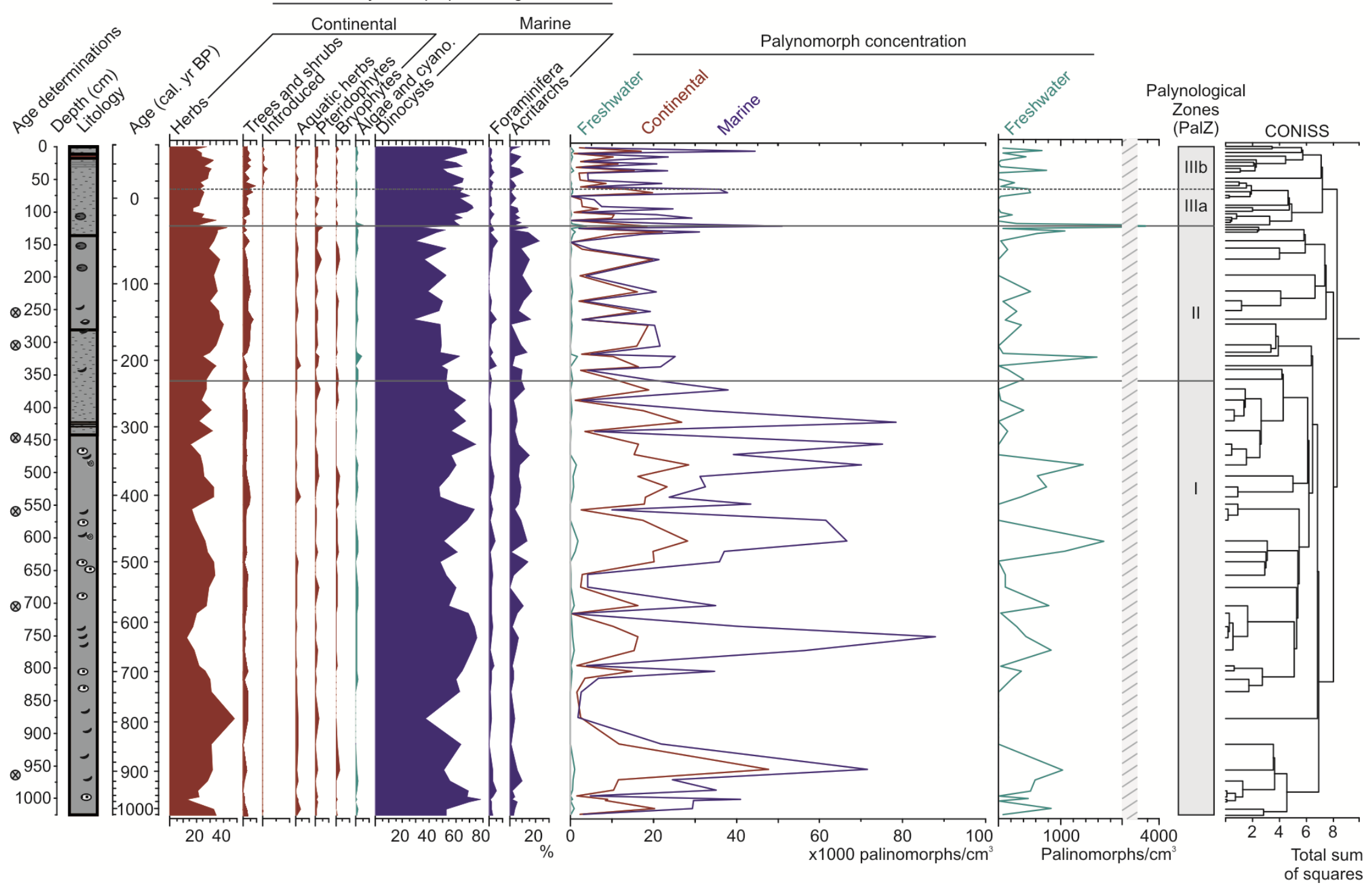

Fig. 5. Summary pollen and NPPs percentage and concentration diagrams, CONISS analysis and Palynological Zones (PalZ) from GeoB13813-4 core. Gray stripes represent axis brake. 
The Patos Lagoon delivers freshwater to the southwestern Atlantic Ocean through a single man-made outlet, where intertidal salt marshes develop (Isaach et al., 2006). Further north, Atlantic rainforest dominates the coastal plains of southern Brazil, represented by species such as ALCHORNEA TRIPLINERVIA and EUTERPE EDULIS, as well as of many MYRTACEAE (Scudeller et al., 2001). In the highlands, the landscape is covered by a mosaic of grassland and Araucaria forests, the latter represented by Araucaria angustifolia, Podocarpus lambertii and Ilex, among others (IBGE, 2012). Therefore, pollen of CYPERACEAE, CHENOPODIOIDEAE and TYPHA (reliable indicators of Patos Lagoon coastal salt marshes; Medeanic, 2006; Medeanic et al., 2007), as well as ARECACEAE, ALCHORNEA, ILEX and PODOCARPUS, could have reached the study site being transported from southern Brazil southwards by the STSW. Morphological characteristics of Podocarpus pollen grains facilitate their dispersal through the air (Lu et al., 2011), so they probably reached the study area by wind transport from Brazil. Southwards, riparian forests and salt marshes developed scattered in the Uruguayan coast, particularly around numerous small water courses that flow into the RdlP and Atlantic Ocean. However, these areas do not seem to provide significant amounts of pollen to the inner continental shelf, given the huge amounts of sediments discharged by the RdIP.

ALNUS and NOTHOFAGUS pollen indicate long distance transport, with ALNUS stemming from the "Yungas" forests of northwestern Argentina, north of latitude $30^{\circ} \mathrm{S}$, and Nothofagus from the foothills of the Andes, south of latitude $37^{\circ} \mathrm{S}$. Both pollen types probably reach the study area by wind, as they have been found in modern surface samples from the campos region overall Uruguay (Mourelle and Prieto, 2012). Nonetheless, Gu et al. (2018b) suggest that NothofAGUS pollen could also reach southwestern Atlantic Ocean transported by rivers draining south and central Argentina. After reaching the ocean, Malvinas Current likely transports NOTHOFAGUS pollen northwards.

The human modification of the campos region, particularly due to the afforestation of economically important tree species, is indicated by PINUS pollen since ca. 1960 AD.

\subsection{Inner Uruguayan continental shelf scenarios of material distribution and accumulation}

5.3.1 From ca. 1000 to $230 \mathrm{cal} \mathrm{yr} \mathrm{BP}(1028-360 \mathrm{~cm}$ depth; PalZ-I - DZ-I to DZ-III)

Marine conditions were inferred by the dominance of marine palynomorphs, both proportion and concentration, mainly represented by Operculodinium centrocarpum dinocyst (Figs. 4, 5). Operculodinium centrocarpum is a cosmopolitan and phototrophic dinocyst recorded in a wide range of temperature (from as low as $6.3^{\circ} \mathrm{C}$ to as high as $23.7^{\circ} \mathrm{C}$ ) and salinity conditions, but highly abundant in sediments below
RESEARCH PAPER the marine Brazil Current (Wall et al., 1977; Zonneveld et al., 2013; Gu et al., 2018a). Its relatively high abundance suggests an influence of the northern warm water masses on the upper section of the water column at the coring site, also supported by the presence of ALCHORNEA and PODOCARPUS pollen, which would have reached the study area carried by STSW waters. Spiniferites spp. are also cosmopolitan and phototrophic dinocysts, very frequent in modern marine sediment (Zonneveld et al., 2013; Gu et al., 2018b). Their presence, together with foraminiferal linings and Michrystridium and Cymatiosphaera acritarchs, supports the inference of a significant marine influence (Borel, 2003) on the inner Uruguayan continental shelf.

This influence of STSW waters is also suggested by the dominance of marine diatoms, mainly Paralia sulcata, and by the high WW diatoms proportions (Fig. 6). Paralia sulcata displays salinity ranges between 15 and 22 (optimum 20), considered as a meso-polihaline diatom (Hassan et al., 2009). WW diatoms are indicative of tropical-subtropical systems (de Wolf, 1982; Hasle and Syvertsen, 1996; Kandari et al., 2009), abundant in sediments underneath the Brazil Current and diminishing in sediments located further south (Romero and Hensen, 2002). Furthermore, and despite the fact that it is not always possible to identify the Chaetoceros species only through the analyses of their resting spores (Ishii et al., 2011), we were able to identify four species that also indicate warm water conditions: Chaetoceros costatus, Chaetoceros seiracanthus, Chaetoceros lorenzianus and Chaetoceros didymus (Hasle and Syversten 1996; Romero and Hensen, 2002; Kandari et al., 2009; Sar et al., 2010). Chaetoceros resting spores could also be suggesting such warm environmental conditions.

In contrast, freshwater input from the mainland to the inner Uruguayan continental shelf is also detected, carrying allochthonous palynomorphs such as algae (Botryococcus and Pediastrum) and cyanobacteria (Gloeotrichia), freshwater diatoms, and terrigenous lithic material rich in $\mathrm{Ti}$ and $\mathrm{Fe}$ from the RdlP watershed (Perez et al., 2018). Freshwater diatoms are almost only represented by Aulacoseira spp. (Perez et al., 2017), a widespread genus inhabiting lacustrine/riverine freshwaters, where it is commonly an important component of the phytoplankton developing under several trophic conditions (Denys et al., 2003; Hassan, 2010). Its co-occurrence together with Paralia sulcata in the sediment of the mud depocenter could be explained by this freshwater input to the inner continental shelf.

However, fluctuations in the palynomorph concentration suggest variable intensity in freshwater input, supported by fluctuating Ti/Ca, Fe/Ca and C/N ratios (Perez et al., 2017, 2018). The progressive decrease in diatom concentration at a time when marine diatoms are replaced by freshwater ones (DZ-IIIa to DZ-IIIb) suggests an increasing intensity of the fluvial input over time. 


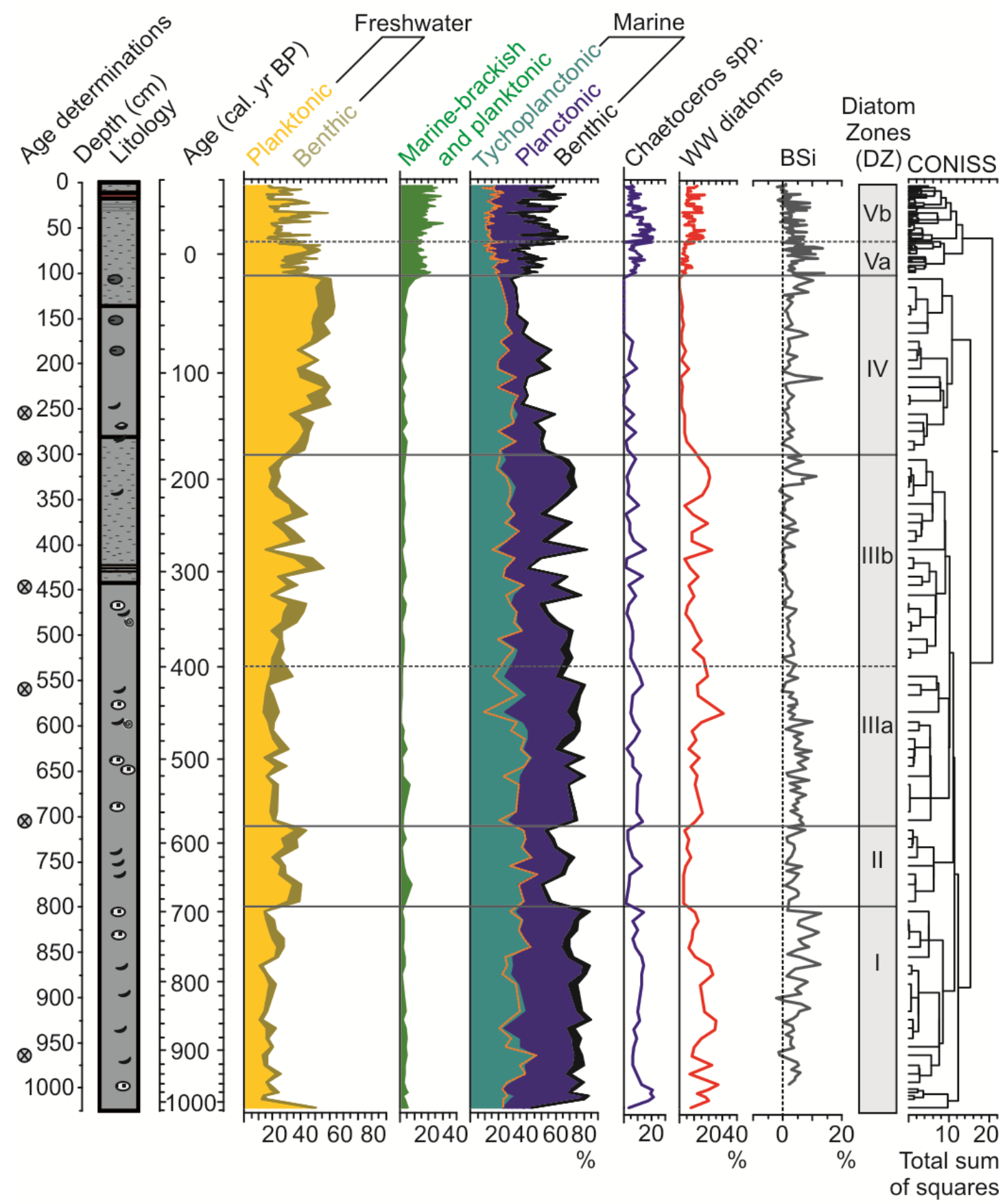

Fig. 6. A) Summary diatom percentage diagram, Chaetoceros spp., warm-water taxa proportion (WW diatoms), Biogenic silica proportion (BSi; Perez et al., 2018), CONISS analysis and Diatom Zones (DZ) from GeoB13813-4 core. Dotted orange line represents Paralia sulcata proportion. Modified from Perez et al. (2017).

Superimposing this general trend, different environmental characteristics are suggested for the time interval at 690 to $575 \mathrm{cal} \mathrm{yr} \mathrm{BP}(800-710 \mathrm{~cm}$ depth; PalZ-I - DZ-II). Increasing freshwater contribution to the inner continental Uruguayan shelf is indicated by the sharp increase in freshwater diatoms relative to the marine species, as well as by a decreasing $\mathrm{BSi}$ proportion, which is interpreted as a depletion of the diatom signal. Nevertheless, marine conditions persisted allowing Paralia sulcata and dinoflagellates to be present.
However, the WW diatoms decrease (mainly Thallassiosira oestrupii and Thalassionema pseudonitzschoides) suggests that the study area was influenced by the cold and less salty SASW marine waters during this time interval. In addition, and since we were not able to identify all the Chaetoceros resting spores, the peak found in this period could correspond to a cold-water influence indicated by species belonging to the Malvinas Current, as it was previously found by Romero and Hensen (2002) for the southwestern Atlantic Ocean. Furthermore, Operculodinium centrocarpum, while indisputably 
abundant in sediments beneath warm water currents, is certainly not limited to warm waters but also abundant underneath cool waters (Wall et al., 1977). Operculodinium centrocarpum cysts are produced by Protoceratium reticulum, a dinoflagellate with a wide geographical distribution, in a range of hydrographic conditions, which comprise different water masses including the Malvinas Current (Akselman, 2015).

5.3.2 From ca. 230 to 25 cal yr BP (1590 to 1925 AD; 360 $115 \mathrm{~cm}$ depth; PalZ-II - DZ-IV)

During this period, a strong influence of RdlP waters, transported via PPW into the inner continental shelf, is indicated by a sharp decrease in marine palynomorphs concentration, within which the dinocyst proportion decreases relative to an increase in acritarchs (Fig. 5). A dinocyst decline could be consequence of an ecological inhibition of dinoflagellates by high turbidity and low salinity (Tyson, 2012), whereas Michrystridium and Cymatiosphaera acritarchs seem to be able to tolerate turbid environments, as suggested by the fossil record from the RdlP northern coast (Mourelle et al., 2015a). High C/N and terrigenous element ratios suggest an increasing supply in suspended continent-derived material (Lamb et al., 2006; Perez et al., 2017, 2018), and historical documents report that since 1975 AD a Paraná Delta high rate of progradation of about 100 $\mathrm{m} \mathrm{yr}^{-1}$ (Barros et al., 2005).

A weak STSW influence is also indicated by very sparse WW diatom taxa, the marine diatoms being replaced by freshwater forms (Fig. 6), mainly Aulacoseira granulata and Aulacoseira ambigua (Perez et al., 2017). These species indicate eutrophic conditions in the RdlP during this time interval, and they are also adapted to live in systems with high amounts of suspended particulate matter, such as the case of RdlP (Licursi et al., 2006).

5.3.3 From ca. $25 \mathrm{cal} \mathrm{yr} \mathrm{BP}$ to the present (1925 AD to the present; $115 \mathrm{~cm}$ depth to the top core; PalZ-III - DZ-V)

Over the past century, a major oceanic influence, mainly by the STSW is suggested by a high marine palynomorph concentration, where dinocyst abundance increased and acritarchs decreased (Fig. 5), thus suggesting the return towards saltier and less turbid waters on the inner Uruguayan continental shelf. This observation is supported by the presence of marine-brackish and marine diatoms (including warm-water indicators), whose abundance significantly increased during this interval. Freshwater input is evidenced by the presence of freshwater algae and cyanobacteria, and of freshwater diatoms (Figs. 5, 6). High $\mathrm{C} / \mathrm{N}$ ratios indicate a significant continental contribution to the sedimentary organic matter composition (Perez et al., 2017).

After ca. 1960 AD (65 cm depth; PalZ-IIb - DZ-Vb) the scenario substantially changes, in parts due to a major influence by the STSW, but mainly due to the anthropogenic impact in the LPDB (Bonachea et al., 2010). Increased erosion by overgrazing, agricultural activities, and deforestation has caused a rise in nutrient levels in the southwestern Atlantic Ocean, as documented by Gu et al. (2018a) for the past 120 years. Eutrophication favors periodic proliferation and dominance of harmful blooms of cyanobacteria, which increases water turbidity and hence restricts light penetration in the affected ecosystems (Paerl and Paul, 2012). Higher Gloeotrichia frequencies reaching the inner continental shelf during this period could be a consequence of such a scenario, as well as a decrease in diatom production (inferred by decreased BSi; Figs. 4, 6). In addition, a high input of nutrients to the coastal ocean is commonly associated with turbidity (Margalef, 1978; Möller et al., 2008), which could have promoted the acritarchs development observed for that period. Such a kind of nutrient enrichment is also suggested by the presence of Actinocyclus normanii diatom and by the highest values in $\delta^{15} \mathrm{~N}$ recorded over the past millennium (Perez et al., 2017). The appearance of PINUS sp. pollen (Fig. 4) is related to forestation activities, strongly promoted during this period (Panario and Gutiérrez, 2007).

\subsection{Southwestern Atlantic Ocean scenarios and paleoclimatic implications}

A southward shift of the ITCZ during Late Holocene would have increased instability and amplified the potential for SWWB wind anomalies which are required to initiate ENSO events (Haug et al., 2001; Lengaigne et al., 2004; Koutavas et al., 2006). Therefore, wetter conditions and higher rainfall over southwestern Atlantic Ocean (Behling, 2002; Behling et al., 2005; Mourelle et al., 2017), in particular during the more frequent El Niño events, could have been originated by increased precipitation over LPDB related with a high ENSO amplitude around $2000 \mathrm{cal} \mathrm{yr} \mathrm{BP} \mathrm{(Woodroffe}$ et al., 2003; Gyllencreutz et al., 2010), displacing the PPW northward and enhancing sediment export to the southwestern Atlantic Ocean (Perez et al., 2017), providing the sediment to the mud depocenter. However, this longterm trend of changing the amount of rainfall over southwestern Atlantic Ocean was overlain by inter-annual to decadal, multi-decadal and centennial variations (Moy et al., 2002), which modulate the RdlP river discharge. Short-term cyclicities $(<100 \mathrm{yr})$ were assigned to the AMO, PDO and ENSO climatic modes, while long-term changes were most probably related to solar forcing (Perez et al., 2018). Terrigenous sediment supply from the RdlP to the Uruguayan continental shelf was strongly controlled by both long-term regional climatic cyclicities as well as inter-annual frequencies (Perez et al., 2018), and the palynological and diatomological assemblages in the record sensitively document these changes (Figs. 5, 6).

From ca. 1000 to $230 \mathrm{cal}$ yr BP, the inner Uruguayan continental shelf was characterized by strong marine influence, more precise the STSW. Such condition has also 
been inferred over the inner continental shelf off southern Brazil (Gu et al., 2017). STSW most likely exerted a major influence on these areas because of the prevalence of northeasterly winds (Perez et al., 2017). Climatically, this period is partially related to the MCA (1050 to $700 \mathrm{cal} \mathrm{yr} \mathrm{BP;}$ 900 to $1250 \mathrm{AD}$ ) and to the LIA (550 to $100 \mathrm{cal} \mathrm{yr} \mathrm{BP;} 1400$ to $1850 \mathrm{AD})$, interpreted as times when the SAMS mean state was first significantly weakening (MCA) and afterwards strengthening again (LIA), respectively (Lamy et al., 2001; Vuille et al., 2012; Apaéstegui et al., 2014; Lüning et al., 2018). Climatic conditions derived from these states seem to correlate well with our observations, in which the lowest freshwater input from mainland to the inner Uruguayan continental shelf took place during the MCA, whereas the trend of increase intensity in freshwater input is partially concomitant to the LIA, which would have caused a northward shift of the PPW.

Between MCA and LIA, our results suggest an influence of SASW on the inner Uruguayan continental shelf. This observation could be explained by a northward shift in SWWB, which entails a northward extension of the Malvinas Current along with a northward shift of the Brazil-Malvinas Confluence Zone (Sijp and England, 2008), supplying cold marine waters into the study area through the STSW. In addition, El Niño events are triggered by atmospheric noise, especially by the SWWB anomalies (Lengaigne et al., 2004; Koffman et al., 2014), and so this SWWB northward extension could be related also to increase rainfall over LPDB. Both the prevalence of the southwesterly winds and the higher terrigenous supply would consequently have provoked a northward displacement of the PPW.

From ca. 230 to 25 cal yr BP, the inner Uruguayan continental shelf was characterized by the strongest influence of RdlP waters overall the period, transported via PPW into the inner continental shelf under low marine influence. Increased influx of water from the main land can be attributed to an increase in precipitation over LPDB and/or a prevalence of the SWWB winds, and consequently a northward displacement of the PPW (Perez et al., 2017). This could suggest strong El Niño activity.

Finally, the period from $1925 \mathrm{AD}$ to the present integrates the Current Warm Period (1900 AD to present), developed on a scenario of anthropogenic climatic change and is characterized by a reduced SASM activity, which happened more abrupt and sustained than the onset of the MCA (Bird et al., 2011). A southward migration of the SWWB took place during Current Warm Period (Bender et al., 2013; Koffman et al., 2014), which might have determined a stronger STSW influence in the study area. However, our major finding clearly highlights a positive trend in yearly averaged precipitation mainly from the late 1960s to the early 1980s (Boulanger et al., 2005). The lower/higher RdlP river discharge before/after 1970 is related to a dominance of $\mathrm{La} \mathrm{Niña} / \mathrm{El}$ Niño events accompanied with a cold/warm PDO phases, and positive/negative AMO phases (Marrero et al., 2014).

\section{Conclusion}

Geographical location, grain size distribution, sedimentation rate, as well as geochemical and biological (palynological and diatomological) analyses indicate a strongly fluctuating fluvio-marine depositional environment over the mud depocenter on the inner Uruguayan continental shelf during Late Holocene. More specifically, the sedimentary record is defined as a marine deposit with a significant admixture of a continuous, powerful fluvial input but with variable intensity of this riverine influence through time.

Freshwater supply carried terrigenous material, such as pollen and spores that were captured by the Paraná and Uruguay rivers flowing through the southeastern South America basin. This palynological material reflects the terrestrial vegetation on the lower reach of the LPDB. Its spectrum mainly represents the regionally dominant grasslands, but also the riparian forests, Butia yatay palm populations, and the herbaceous-bushy marshes around the mouth of the estuary. Such results reflect stable plant communities at regional scale for the last 1000 cal yr BP, which are in agreement with other studies from the campos region and adjacent areas.

Palynological data also evidence that pollen from remote phytogeographical areas reaches the study site, mainly transported (1) by coastal ocean currents from salt marshes, Atlantic rainforest, and Araucaria forests in southern Brazil; and (2) by wind from Andean forests. This long-distance transported pollen highlights the high paleobotanical potential of this sequence, because of capturing pollen from a large regional scale.

Ecological information provided by changes in dinocysts, acritarchs, algae and cyanobacteria proportion and concentrations in GeoB13813-4 sediments represent a new line of evidence of changes in terrestrial run-off to the inner Uruguayan continental shelf, mainly related to a variable precipitation regime over LPDB, in addition to ocean hydrography and wind activity. The main scenarios characterizing the environmental dynamics include:

(1) From ca. 1000 to $230 \mathrm{cal}$ yr BP: significant marine STSW influence was inferred, diluted by the freshwater supply from the Uruguayan mainland of increased intensity over time. Climatically, this period is partially related to the MCA and the LIA, when the SAMS mean state was first significantly weakening (MCA) and thereafter strengthening again (LIA), with the consequent lower/higher freshwater contributions into the inner Uruguayan continental shelf, respectively.

(2) This period was interrupted between ca. 690 to 575 cal yr BP by increased freshwater contribution under SASW influence. This observation could be explained by a northward shift in SWWB, which entails a northward extension of the Malvinas Current along with a northward shift of the Brazil-Malvinas Confluence Zone.

(3) From ca. 230 to $25 \mathrm{cal}$ yr BP, a strong influence of RdlP waters was detected that could be attributed to an 
increase in precipitation over LPDB and/or a prevalence of the SWWB winds, thus suggesting a strong El Niño activity and a northward displacement of the PPW.

(4) Return to dominant STSW over the past century, climatically related to the Current Warm Period developed on a scenario of anthropogenic climatic change characterized by a reduced SASM activity. In particular, after ca. 1960 AD the anthropogenic impact within the LPDB was evidenced by both eutrophication and the appearance of PINUS sp. pollen.

\section{Acknowledgment}

This study was supported by PEDECIBA (Programa para el Desarrollo de las Ciencias Básicas) Geociencias, ANII (Agencia Nacional de Investigación e Innovación) and DAAD (German Academic Exchange Service). Sample material has been provided by the by the GeoB core repository at the MARUM - Center for Marine Environmental Sciences, University of Bremen, Germany. The data reported in this paper are archived in Pangaea (www.pangaea.de). We thank R. Odino and the Dinamige for giving support during the laboratory work. Special thanks to A. R. Prieto and the anonymous reviewers for their comments and suggestions which improved the final version.

\section{References}

Acha, E.M., Mianzan, H., Guerrero, R., Carreto, J., Giberto, D., Montoya, N., Carignan, M., 2008. An overview of physical and ecological processes in the Rio de la Plata Estuary. Continental Shelf Research 28, 15791588. https://doi.org/10.1016/j.csr.2007.01.031

Akselman, R., Krock, B., Alpermann, T.J., Tillmann, U., Borel, C.M., Almandoz, G.O., Ferrario, M.E., 2015. Protoceratium reticulatum (Dinophyceae) in the austral Southwestern Atlantic and the first report on YTX-production in shelf waters of Argentina. Harmful algae 45, 40-52. https://doi.org/10.1016/j.hal.2015.03.001

Alves, E., Macario, K., Souza, R., Pimenta, A., Douka, K., Oliveira, F., Chanca, I., Angulo, R., 2016. Corrigendum to 'Radiocarbon reservoir corrections on the Brazilian coast from prebomb marine shells'[Quat. Geochronol. 29 (2015) 30-35]. Quaternary Geochronology 31, 1-2.

Anderson, D.M., 2007. Paleoceanography. In: Elias, S. (ed.), Encyclopedia of Quaternary Science, Amsterdam, Elsevier, pp. 1599-1609.

Andrade, B.O., Marchesi, E., Burkart, S., Setubal, R.B., Lezama, F., Perelman, S., Schneider, A.A., Trevisan, R., Overbeck, G.E. Boldrini, I.I., 2018. Vascular plant species richness and distribution in the Río de la Plata grasslands. Botanical Journal of the Linnean Society 188, 250-256. https://doi.org/10.1093/botlinnean/boy063

Apaéstegui, J., Cruz, F.W., Sifeddine, A., Espinoza, J.C., Guyot, J.L., Khodri, M., Strikis, N., Santos, R.V., Cheng, H., Edwards, L., Carvalho, E., Santini, W., 2014. Hydroclimate variability of the South American Monsoon System during the last $1600 \mathrm{yr}$ inferred from speleothem isotope records of the north-eastern Andes foothills in Peru. Climate of the Past - Discussions 10, 533-561. https://doi.org/10.5194/cpd-10-533-2014
RESEARCH PAPER

Barreiro, M., 2010. Influence of ENSO and the South Atlantic Ocean on climate predictability over Southeastern South America. Climate Dynamics 35, 1493-1508. https://doi.org/10.1007/s00382-009-0666-9

Barros, V.B., Menéndez, Á., Natenzon, C., Codignotto, O., Kokot, R., Bischoff, S., 2005. El cambio climático y la Costa Argentina del Río de la Plata. Buenos Aires: Fundación Ciudad.

Bauermann, S.G., Radaeski, J.N., Evaldt, A.C.P., Queiroz, E.P., Mourelle, D., Prieto, A.R., da Silva, C.I., 2013. Pólen nas Angiospermas: diversidade e evolução. Rio Grande do Sul. Editora da ULBRA.

Behling, H., Pillar, V.D., Bauermann, S.G., 2005. Late Quaternary grassland (Campos), gallery forest, fire and climate dynamics, studied by pollen, charcoal and multivariate analysis of the São Francisco de Assis core in western Rio Grande do Sul (southern Brazil). Review of Palaeobotany and Palynology 133, 235-248. https://doi.org/10.1016/j.revpalbo.2004.10.004

Behling, H., Arz, H.W., Pätzold, J., Wefer, G., 2002. Late Quaternary vegetational and climate dynamics in southeastern Brazil, inferences from marine cores GeoB 3229-2 and GeoB 3202-1. Palaeogeography, Palaeoclimatology, Palaeoecology 179, 227-243. https://doi.org/10.1016/S0031-0182(01)00435-7

Behling, H., 2002. South and Southeast Brazilian grasslands during Late Quaternary times: a synthesis. Palaeogeography, Palaeoclimatology, Palaeoecology 177, 19-27. https://doi.org/10.1016/S0031-0182(01)00349-2

Bender, V.B., Hanebuth, T.J.J., Chiessi, C.M., 2013. Holocene shifts of the Subtropical Shelf Front off southeastern South America controlled by high and low latitude atmospheric forcings. Paleoceanography 28, 481-490. https://doi.org/10.1002/palo.20044

Bilenca, D., Miñarro, F., 2004. Identificación de Áreas Valiosas de Pastizal (AVPs) en las Pampas y Campos de Argentina, Uruguay y sur de Brasil. Buenos Aires: Fundación Vida Silvestre Argentina.

Bird, B.W., Abbott, M.B., Vuille, M., Rodbell, D.T., Stansell, N.D., Rosenmeier, M.F., 2011. A 2,300-year-long annually resolved record of the South American summer monsoon from the Peruvian Andes. Proceedings of the National Academy of Sciences 108, 8583-8588. https://doi.org/10.1073/pnas.1003719108

Blaauw, M., Christen, J.A., 2011. Flexible paleoclimate age-depth models using an autoregressive gamma process. Bayesian Analysis 6, 457-474.

Borel, C.M., 2007. Algas no silíceas y acritarcos de depósitos costeros holocenos en el arroyo La Ballenera, Buenos Aires, Argentina. Ameghiniana 44, 359-366.

Borel, C.M., 2003. Palinología (con énfasis en algas y acritarcos) del Holoceno del sud-sudeste bonaerense: su importancia paleoecológica. PhD thesis, Universidad Nacional del Sur, Bahía Blanca.

Borel, C.M., Guerstein, G.R., Prieto, A.R., 2003. Palinomorfos acuáticos (algas y acritarcos) del Holoceno de la laguna Hinojales (Buenos Aires, Argentina): interpretación paleoecológica. Ameghiniana 40, 531-544.

Boulanger, J.P., Leloup, J., Penalba, O., Rusticucci, M., Lafon, F., Vargas, W., 2005. Observed precipitation in the Paraná-Plata hydrological basin: long-term trends, extreme conditions and ENSO teleconnections. Climate Dynamics 24, 393-413. https://doi.org/10.1007/s00382-004-0514-x 
Brussa, C.A., Grela, I., 2007. Flora Arbórea del Uruguay. Con énfasis en las especies de Rivera y Tacuarembó. Montevideo: COFUSA.

Cavallotto, J.L., Violante, R.A., 2005. Geología y Geomorfología del Río de la Plata. In: deBarrio, R. E., Etcheverry, M. F., Caballé, M. F., Llambias, E. (Eds.), Geología y Recursos Minerales de la Provincia de Buenos Aires, La Plata, Relatorio del XVI Congreso Geológico Argentino, pp. 237-254.

Cavallotto, J.L., Violante, R.A., Parker, G., 2004. Sea-level fluctuations during the last 8600 years in the de la Plata river (Argentina). Quaternary International 114, 155-165. https://doi.org/10.1016/S1040-6182(03)00050-8

Cavallotto, J.L., 2002. Evolución holocena de la llanura costera del margen sur del Río de la Plata. Revista de la Associación Geológica Argentina 57, 376-388.

Chiessi, C.M., Mulitza, S., Patzold, J., Wefer, G., Marengo, J.A., 2009. Possible impact of the Atlantic Multidecadal Oscillation on the South American summer monsoon. Geophysical. Research Letters 36, L21707. https://doi.org/10.1029/2009GL039914.

Dai, L., Weng, C., Lu, J., Mao, L., 2014. Pollen quantitative distribution in marine and fluvial surface sediments from the northern South China Sea: new insights into pollen transportation and deposition mechanisms. Quaternary International 325, 136-149. https://doi.org/10.1016/j.quaint.2013.09.031

de Klerk, P., Joosten, H., 2007. The difference between pollen types and plant taxa: a plea for clarity and scientific freedom. Quaternary Science Journal 56, 162-171. http://dx.doi.org/10.23689/fidgeo-1295

del Puerto, L., Bracco, R., Inda, H., Gutiérrez, O., Panario, D., García-Rodríguez, F., 2013. Assessing links between late Holocene climate change and paleolimnological development of Peña Lagoon using opal phytoliths, physical, and geochemical proxies. Quaternary International 287, 89-100. https://doi.org/10.1016/j.quaint.2011.11.026

del Puerto, L., 2009. Reconstrucción Paleoclimática y Paleoambiental para el Pleistoceno Tardío / Holoceno en el Sudeste del Uruguay: aporte del análisis de silicofitolitos. MSc Thesis, Facultad de Ciencias. Universidad de la República, Montevideo.

Denys, L., Muylaert, K., Krammer, K., Joosten, T., Reid, M., Rioual, P., 2003. Aulacoseira subborealis stat. nov. (Bacillariophyceae): a common but neglected plankton diatom. Nova Hedwigia 77, 407-427. https://doi.org/10.1127/ 00295035/ 2003/0077-0407

Depetris, P. J., Pasquini, A.I., 2007. Discharge trends and flow dynamics of southern south American rivers draining the southern Atlantic seaboard: an overview. Journal of Hydrology 333, 385-399. https://doi.org/10.1016/j.hydrol.2006.09005.

Depetris, P.J., Probst, J.-L., Pasquini, A.I., Gaiero, D.M., 2003. The geochemical characteristics of the Paraná River suspended sediment load: an initial assessment. Hydrological Processes 17, 1267-1277. https://doi.org/10.1002/hyp.1283.

de Wolf, H., 1982. Method of coding of ecological data from diatoms for computer utilization. Mededelingen - Rijks Geologische Dienst 36, 95-98.

Dixon, A. P., Faber-Langendoen, D., Josse, C., Morrison, J., Loucks, C.J., 2014. Distribution mapping of world grassland types. Journal of Biogeography 41, 2003-2019. https://doi.org/10.1111/jbi.12381
RESEARCH PAPER

Dupont, L. M., 1999. Pollen and spores in marine sediments from east Atlantic -A view from the Ocean into the African continent. In: Fischer, G., Wefer, G. (Eds.), Use of proxies in Paleoceanography: Examples from the South Atlantic, Verlag Berlin Heidelberg, Springer, pp. 523-546.

Fægri, K., Iversen, J., 1989. Textbook of Pollen Analysis. New York: John Wiley \& Sons.

García-Rodríguez, F., Brugnoli, E., Muniz, P., Venturini, N., Burone, L., Hutton, M., Rodríguez, M., Pita, A., Kandratavicius, N., Perez, L., Verocai, J., 2014. Warm-phase ENSO events modulate the continental freshwater input and the trophic state of sediments in a large South American estuary. Marine and Freshwater Research 65, 1-11. https://doi.org/10.1071/MF13077

García-Rodríguez, F., Stutz, S., Inda, H., del Puerto, L., Bracco, R., Panario, D., 2010. A multiproxy approach to inferring Holocene paleobotanical changes linked to sea-level variation, paleosalinity levels, and shallow lake alternative states in Negra Lagoon, SE Uruguay. Hydrobiologia 646, 5-20. https://doi.org/10.1007/s10750-010-0184-0

Garreaud, R.D., Vuille, M., Compagnucci, R., Marengo, J., 2009. Present-day South American climate. Palaeogeography, Palaeoclimatology, Palaeoecology 281, 180-195. https://doi.org/10.1016/j.palaeo.2007.10.032

Grimm, E.C., 2004. Tilia Software 2.0.4. Springfield, Illinois. Illinois State Museum. Research and Collection Center.

Gu, F., Chiessi, C.M., Zonneveld, K.A., Behling, H., 2018a. Shifts of the Brazil-Falklands/Malvinas Confluence in the western South Atlantic during the latest Pleistocene-Holocene inferred from dinoflagellate cysts. Palynology 1-11. https://doi.org/10.1080/01916122.2018.1470116

Gu, F., Chiessi, C.M., Zonneveld, K.A., Behling, H., 2018b. Late Quaternary environmental dynamics inferred from marine sediment core GeoB6211-2 off southern Brazil. Palaeogeography, Palaeoclimatology, Palaeoecology 496, 4861. https://doi.org/10.1016/j.palaeo.2018.01.015

Gu, F., Zonneveld, K.A., Chiessi, C.M., Arz, H.W., Pätzold, J., Behling, H., 2017. Long-term vegetation, climate and ocean dynamics inferred from a 73,500 years old marine sediment core (GeoB2107-3) off southern Brazil. Quaternary Science Reviews 172, 55-71. https://doi.org/10.1016/j.quascirev.2017.06.028

Guerrero, R.A., Acha, E.M., Framiñan, M.B., Lasta, C.A., 1997. Physical oceanography of the Rio de la Plata Estuary, Argentina. Continental Shelf Research 17, 727-742. https://doi.org/10.1016/S0278-4343(96)00061-1

Geymonat, G., Rocha, N., 2009. M’butiá Ecossistema único en el mundo. Casa Ambiental, Castillos, Rocha, Uruguay. Glassman.

Gyllencreutz, R., Mahiques, M.M., Alves, D.V.P., Wainer, I.K.C., 2010. Mid- to late Holocene paleoceanographic changes on the southeastern Brazilian shelf based on grain size records. The Holocene 20, 863-875. https://doi.org/10.1177/0959683610365936

Haug, G.H., Hughen, K.A., Sigman, D.M., Peterson, L.C., Röhl, U., 2001. Southward migration of the Intertropical Convergence Zone through the Holocene. Science 293, 13041308.

Hasle, G.R., Syvertsen, E.E., 1996. Marine diatoms. In: Tomas, C. R. (Ed.), Identifying Marine Phytoplankton, San Diego, Academic Press, pp. 5-385. 
Hassan, G., 2010. Paleoecological significance of diatoms in Argentinean estuaries: what do they tell us about the environment? In: Crane, J. R., Solomon, A. E. (Eds.). Estuaries: types, movement patterns and climatical impacts, New York, Nova Science Publishers, pp. 71-147.

Hassan, G.S., Espinosa, M.A., Isla, F.I., 2009. Diatom-based inference model for paleosalinity reconstructions in estuaries along the northeastern coast of Argentina. Palaeogeography, Palaeoclimatology, Palaeoecology 275, 77-91.

IBGE, 2012. Manual técnico da vegetação brasileira: sistema fitogeográfico, inventário das formações florestais e campestres, técnicas e manejo de coleções botânicas, procedimentos para mapeamentos. IBGE, Coordenação de Recursos Naturais e Estudos Ambientais, 233 p. https://biblioteca.ibge.gov.br/index.php/bibliotecacatalogo?view $=$ detalhes\&id $=263011$

Iriarte, J., 2006. Vegetation and climate change since $14.810{ }^{14} \mathrm{C} \mathrm{yr}$. B.P. in southeastern Uruguay and implications for the rise of early Formative societies. Quaternary Research 65, 20-32. https://doi.org/10.1016/j.yqres.2005.05.005

Isacch, J.P., Costa, C.S.B., Rodríguez-Gallego, L., Conde, D., Escapa, M., Gagliardini, D. A., Iribarne, O.O., 2006. Distribution of saltmarsh plant communities associated with environmental factors along a latitudinal gradient on the southwest Atlantic coast. Journal of Biogeography 33, 888-900. https://doi.org/10.1111/j.1365-2699.2006.01461.x

Ishii, K.-I., Iwataki, M., Matsuoka K., Imai, I., 2011. Proposal of identification criteria of resting spores of Chaetoceros species (Bacillariophyceae) from a temperate coastal sea. Phycology. 50, 351-362. https://doi.org/10.2216/10-36.1

Kandari, M., Rifaie, K., Yamani, F.Y., 2009. Diatoms. In: Kandari, M., Rifaie, K., Yamani, F.Y. (Eds.). Marine phytoplankton atlas of Kuwait's water. Kuwait Institute for Scientific Research, Kuwait, pp. 26-136.

Koffman, B.G., Kreutz, K.J., Breton, D.J., Kane, E.J., Winski, D.A., Birkel, S.D., Kurbatov, A.V., Handley, M. J., 2014. Centennial-scale variability of the Southern Hemisphere westerly wind belt in the eastern Pacific over the past two millennia. Climate of the Past 10: 1125-1144. https://doi.org/10.5194/cp-10-1125-2014.

Koutavas, A., Olive, G.C., Lynch-Stieglitz, J., 2006. Mid-Holocene El Niño-Southern Oscillation (ENSO) attenuation revealed by individual foraminifera in eastern tropical Pacific sediments. Geology 34, 993-996.

Krastel, S., Wefer, G., 2012. Report and preliminary results of RVMETEOR CruiseM78/3. Sediment Transport off Uruguay and Argentina: From the Shelf to the Deep Sea; 19.05.200906.07.2009, Montevideo (Uruguay)-Montevideo (Uruguay) Berichte aus dem Fachbereich Geowissenschaften 285 (Fachbereich Geowissenschaften, Bremen).

Lamb, A.L., Wilson, G.P., Leng, M.J., 2006. A review of coastal palaeoclimate and relative sea-level reconstructions using $\delta^{13} \mathrm{C}$ and $\mathrm{C} / \mathrm{N}$ ratios in organic material. Earth-Science Reviews 75, 29-57. https://doi.org/10.1016/j.earscirev.2005.10.003

Lamy, F., Hebbern, D., Rohn, U., Wefer, G., 2001. Holocene rainfall variability in southern Chile: a marine record of latitudinal shifts of the southern westerlies. Earth and Planetary Science Letters 185: 369-382. https://doi.org/10.1016/S0012$821 \mathrm{X}(00) 00381-2$

Lantzsch, H., Hanebuth, T.J., Chiessi, C. M., Schwenk, T., Violante, R.A., 2014. The high-supply, current-dominated continental margin of southeastern South America during the late Quaternary. Quaternary Research 81, 339-354. https://doi.org/10.1016/j.yqres.2014.01.003

Lengaigne, M., Guilyardi, E., Boulanger, J. P., Menkes, C., Delecluse, P., Inness, P., Cole, J., Slingo, J., 2004. Triggering of El Niño by westerly wind events in a coupled general circulation model. Climate Dynamics 23, 601-620. https://doi.org/10.1007/s00382-004-0457-2

León, R.J.C., 1991. Río de la Plata grasslands. In: Coupland, R.T. (Ed.), Natural grasslands: introduction and western hemisphere. Ecosystems of the World, Amsterdam, Elsevier, pp. 369-376, 380-387.

Lezama, F., Altesor, A., Pereira, M., Paruelo, J.M., 2011. Capítulo I. Descripción de la heterogeneidad florística de los pastizales naturales de las principales regiones geomorgológicas de Uruguay. In: Altesor, A., Ayala, W., Paruelo, J. M. (Eds.), Bases ecológicas y tecnológicas para el manejo de pastizales, Montevideo, Serie FPTA- INIA, pp. 15-32.

Licursi, M., Sierra, M. V., Gómez, N., 2006. Diatom assemblages from a turbid coastal plain estuary: Río de la Plata (South America). Journal of Marine Systems 62, 35-45. https://doi.org/10.1016/j.jmarsys.2006.03.002

Lu, Y., Jin, B., Wang, L., Wang, Y., Wang, D., Jiang, X.X., Chen, P., 2011. Adaptation of male reproductive structures to wind pollination in gymnosperms: cones and pollen grains. Canadian Journal of Plant Science 91, 897-906. https://doi.org/10.4141/CJPS2011-020

Lüning, S., Gałkab, M., Bamonte, F.P., García-Rodríguez, F., Vahrenholt, F., 2018. The Medieval Climate Anomaly in South America. Quaternary Internacional (in press). https://doi.org/10.1016/j.quaint.2018.10.041

Mahiques, M.M., Wainer, I.K.C., Burone, L., Nagai, R., Sousa, S. H. M., Figueira, R.C.L.-., Silveira, I.C.A., Bícego, M.C., Alves, D.P.V., Hammer, O., 2009. A high-resolution Holocene record on the Southern Brazilian shelf: Paleoenvironmental implications. Quaternary International 206, 52-61. https://doi.org/10.1016/j.quaint.2008.09.010

Marchetti, Z.Y., Latrubesse, E.M., Pereira, M.S., Ramonell, C.G., 2013. Vegetation and its relationship with geomorphologic units in the Parana River floodplain, Argentina. Journal of South American Earth Sciences 46, 122-136. https://doi.org/10.1016/j.jsames.2013.03.010

Margalef, R., 1978. Life-forms of phytoplankton as survival alternatives in an unstable environment. Oceanologica Acta 1, 493-509. https://archimer.ifremer.fr/doc/00123/23403/

Marrero, A., Tudurí, A., Perez, L., Cuña, C., Muniz, P., Lopes Figueira, R.C., Mahiques, M.M., Alves de Lima Ferreira, P., Pittauerová, D., Hanebuth, T.J.J., 2014. Cambios históricos en el aporte terrígeno de la cuenca del Río de la Plata sobre la plataforma interna Uruguaya. Latin American Journal of Sedimentology and Basin Analysis 21, 165-179.

Metzeltin, D., Lange-Bertalot, H., García-Rodríguez, F., 2005. Diatoms of Uruguay - Taxonomy, Biogeography, Diversity. Koenigstein: Gantner Verlag, A.R.G.

Metzeltin, D., García-Rodríguez, F., 2003. Las Diatomeas Uruguayas. Montevideo: Facultad de Ciencias.

MGAP-DIEA. 2011. Censo General Agropecuario 2011. Resultados definitivos. Montevideo: Ministerio de Ganadería, Agricultura y Pesca.

Möller Jr., O.O., Piola, A.R., Freitas, A.G., Campos, E.J.D., 2008. The effects of river discharge and seasonal winds on the shelf 
off southeastern South America. Continental Shelf Research 28, 1607-1624. https://doi.org/10.1016/j.csr.2008.03.012

Mourelle, D., Macedo, R.B., Prieto, A.R., 2018. Análisis palinológico actual y del Cuaternario Tardío en la región de los campos (Uruguay y sur de Brasil): estado de las investigaciones, dificultades y potencialidades. In: Prieto, A. R. (Ed.), Metodologías y estrategias del análisis palinológico del Cuaternario tardío. Publicación Electrónica de la Asociación Paleontológica Argentina 18, 156-170. https://doi.org/10.5710/PEAPA.28.05.2018.258

Mourelle, D., Prieto, A. R., García-Rodríguez, F., 2017. Riparian woody vegetation history in the campos region, Southeastern South America, during two-time windows: late Pleistocene and late Holocene. Quaternary Science Reviews 167, 14-29. https://doi.org/10.1016/j.quascirev.2017.04.024

Mourelle, D., Prieto, A.R., 2016. Pollen and spores from surface samples in the campos region of Uruguay and their paleoecological implications. Acta Botanica Brasilica 30, 351 370. https://doi.org/10.1590/0102-33062016abb0117

Mourelle, D., Prieto, A.R., Pérez, L., García-Rodríguez, F., Borel, C.M., 2015a. Mid and late Holocene multiproxy analysis of environmental changes linked to sea-level fluctuation and climate variability of the Río de la Plata estuary. Palaeogeography, Palaeoclimatology, Palaeoecology 421, 7588. https://doi.org/10.1016/j.palaeo.2015.01.006

Mourelle, D., Prieto, A.R., García-Rodríguez, F., 2015b. Cambios de la vegetación en la cuenca de la Laguna Merín, Uruguay, durante los últimos ca. 2000 cal. años AP. Revista Brasileira de Paleontologia 18, 509-520. https://doi.org/10.4072/rbp.2015.3.13

Mourelle, D., Prieto, A.R., 2012. Modern pollen assemblages of surface samples and their relationships to vegetation in the campos region of Uruguay. Review of Palaeobotany and Palynology 181, 22-33. https://doi.org/10.1016/j.revpalbo.2012.05.003

Moy, C.M., Seltzer, G.O., Rodbell, D.T., Anderson, D.M., 2002. Variability of El Niño/Southern Oscillation activity at millennial timescales during the Holocene epoch. Nature 420, 162-165.

Muñoz, N.E., 2017. Estudio palinológico (de superficie y aéreo) del pastizal-palmar del Parque Nacional El Palmar (Colón, Entre Ríos): generación de un modelo análogo. PhD Thesis, Universidad Nacional de Córdoba, Córdoba.

Paerl, H.W., Paul, V.J., 2012. Climate change: links to global expansion of harmful cyanobacteria. Waterresearch 46, 13491363. https://doi.org/10.1016/j.watres.2011.08.002

Palma, E.D., Matano, R.P., Piola, A.R., 2008. A numerical study of the Southwestern Atlantic Shelf circulation: Stratified ocean response to local and offshore forcing. Journal of Geophysical Research Oceans 113, C11. https://doi.org/10.1029/2007JC004720

Panario, D., Gutiérrez, O., 2007. La política forestal industrial del estado uruguayo. In: Política y Pasteras en el Rio Uruguay: Medio Ambiente, Modelos Productivos y Movimiento Social, Buenos Aires, pp. 1-9.

Paruelo, J. M., Piñeiro, G., Altesor, A., Rodríguez, C., Oesterheld, M., 2004. Cambios estructurales y funcionales asociados al pastoreo en los Pastizales del Río de la Plata. In: XX Reunión del grupo Campos-Cono Sur, Salto, pp. 53-60.

Patterer, N.I., Zucol, A.F., Passeggi, E., 2017. Análisis fitolíticos en suelos formados sobre antiguas terrazas del Río Uruguay (Colón, Entre Ríos): primera evidencia de retracción de los
RESEARCH PAPER palmares de Butia yatay (Mart.). Becc. Publicación Electrónica de la Asociación Paleontológica Argentina 17, 1-17. https://doi.org/10.5710/PeaPa.20.03.2017.122

Pasquini, A.I., Depetris, P.J., 2007. ENSO-triggered exceptional flooding in the Paraná River: where is the excess water coming from? Journal of Hydrology 383 (2010), 186-193. https://doi.org/10.1016/j.jhydrol.2009.12.035

Perez, P., Crisci, C., Hanebuth, T.J.J., Lantzsch, H., Perera, H., Rodríguez, M., Pérez, A., Fornaro, L., García-Rodríguez, F., 2018. Climatic oscillations modulating the Late Holocene fluvial discharge and terrigenous material supply of the Río de la Plata into the Southwestern Atlantic Ocean. Journal of Sedimentary Environments, 3 (4): 205-219. https://doi.org/10.12957/jse.2018.38983

Perez, L., García-Rodríguez, F., Hanebuth, T.J.J., 2017. Paleosalinity changes in the Río de la Plata estuary and on the adjacent Uruguayan continental shelf over the past 1,200 cal ka BP: an approach using diatoms as proxy. In: Weckström, K., Saunders, P.G.K., Skilbeck, G. (Eds.), Applications of paleoenvironmental techniques in estuarine studies, Developments in Paleoenvironmental Research (DPER), Springer.

Perez, L., García-Rodríguez, F., Hanebuth, T.J.J., 2016. Variability in terrigenous sediment supply offshore of the Rio de la Plata (Uruguay) recording the continental climatic history over the past 1200 years. Climate of the Past 12, 623-634. https://doi.org/10.5194/cp-12-623-2016

Petraglia, C., Dell'Acqua, M., 2006. Actualización de la carta forestal del Uruguay con imágenes del año 2004. Sistema de Información Geográfica de la Dirección General de Recursos Naturales Renovables (DGRNR) - Ministerio de Ganadería, Agricultura y Pesca (MGAP). Montevideo, $27 \mathrm{p}$.

Piola, A.R., Möller Jr., O.O., Guerrero, R.A., Campos, E.J.D., 2008. Variability of the subtropical shelf front off eastern South America: Winter 2003 and summer 2004. Continental Shelf Research 28, 1639-1648. https://doi.org/10.1016/j.csr.2008.03.013

Piola, A.R., Matano, R.P., Palma, E.D., Möller Jr., O.O., Campos, E.J.D., 2005. The influence of the Plata River discharge on the western South Atlantic shelf. Geophysical Research Letters 32, L01603. https://doi.org/10.1029/2004GL021638

Piola, A.R., Campos, E.J.D., Möller Jr., O.O., Charo, M., Martinez, C., 2000. Subtropical Shelf Front off eastern South America. Journal of Geophysical Research 105, 6565-6578. https://doi.org/10.1029/1999JC000300

Prieto, A.R., Mourelle, D., Peltier, W.R., Drummond, R., Vilanova, I., Ricci, L., 2017. Relative sea-level changes during the Holocene in the Río de la Plata, Argentina and Uruguay: A review. Quaternary Internacional 442, 35-49. https://doi.org/10.1016/j.quaint.2016.02.044

Razik, S., Chiessi, C. M., Romero, O.E., von Dobeneck, T., 2013. Interaction of the South American Monsoon System and the Southern Westerly Wind Belt during the last 14 kyr. Palaeogeography, Palaeoclimatology, Palaeoecology 374, 2840. https://doi.org/10.1016/j.palaeo.2012.12.022

Reimer, P.J., Bard, E., Bayliss, A., Beck, J.W., Blackwell, P.G., Ramsey, C.B., Buck, C.E., et al., 2013. IntCal13 and Marine13 radiocarbon age calibration curves 0-50,000 years cal BP. Radiocarbon 55, 1869-1887. https://doi.org/10.2458/azu_js_rc.55.16947

Romero, O.E., Hensen, C., 2002. Oceanographic control of the biogenic opal and diatoms in surface sediments of the 
Southwestern Atlantic. Marine Geology 186, 263-280. https://doi.org/10.1016/S0025-3227(02)00210-4

Sar, E. A., Sunesen, I., Lavigne, A. S., 2010. Cymatotheca, Tryblioptychus, Skeletonemaand Cyclotella (Thalassiosirales) from Argentinian coastal waters. Description of Cyclotellacubiculata sp. nov. Vie Milieu 60, 135-156.

Sijp, W.P., England, M.W., 2008. The effect of a northward shift in the southern hemisphere westerlies on the global ocean. Progress in Oceanography 79, 1-19. https://doi.org/10.1016/j.pocean.2008.07.002

Scudeller, V.V., Martins, F.R., Shepherd, G.J. 2001. Distribution and abundance of arboreal species in the atlantic ombrophilous dense forest in Southeastern Brazil. Plant Ecology 152, 185199. https://doi.org/10.1023/A:1011494228661

Sobral, M., Jarenkow, J.A., Brack, P., Irgang, B., Larocca, J., Rodrigues, R.S., 2006. Flora arbórea e arborescente do Rio Grande do Sul. São Carlos. RiMa: Novo Ambiente.

Soriano, A., 1991. Río de la Plata grasslands. In: Coupland, R. T. (Ed.), Natural grasslands: introduction and western hemisphere. Ecosystems of the World, Amsterdam, Elsevier, pp. 367-369.

Stockmarr, J., 1971. Tablets with spores used in absolute pollen analysis. Pollen et Spores 13, 615-621. https://doi.org/10.1177/0959683615574584

Tyson, R. V., 2012. Sedimentary organic matter: organic facies and palynofacies. Devon, Springer Science \& Business Media.

van Geel, B., 2001. Non-pollen palynomorphs. In: Smol, J.P., Birks, H.J.B., Last, W.M. (Eds.), Tracking Environmental Change Using Lake Sediments. Volumen 3: Terrestrial, Algal and Siliceous Indicators, Dordrecht, Kluwer Academic Publishers, pp. 99-119.

Vera, C., Higgins, W., Amador, J., Ambrizzi, T., Garreaud, R. D., Gochis, D., Gutzler, D., Lettenmaier, D., Marengo, J., Mechoso, C.R., Nogues-paegle, J., Silva Dias, P.L., Zhangl, C., 2006. Toward a Unified View of the American Monsoon Systems. journal of Climate - Special Section 19, 4977-5000. https://doi.org/10.1175/JCLI3896.1
RESEARCH PAPER

Vernal, A., 2009. Marine palynology and its use for studying nearshore environments. Earth and Environmental Science 5, 012002. https://doi.org/10.1088/1755-1307/5/1/012002

Vilanova, I., Prieto, A.R., 2012. Historia de la vegetación de las llanuras costeras de la Bahía Samborombón ( 35,5요 $\mathrm{S}$, Argentina, desde $7800{ }^{14} \mathrm{C}$ años. Ameghiniana 49, 303-318. https://doi.org/10.5710/AMGH.v49i3(499)

Vuille, M., Burns, S.J., Taylor, B.L., Cruz, F.W., Bird, B.W., Abbott, M.B., Kanner, L.C., Cheng, H., Novello, V. F., 2012. A review of the South American monsoon history as recorded in stable isotopic proxies over the past two millennia. Climate of the Past 8, 1309-1321. https://doi.org/10.5194/cp-8-1309-2012

Wall, D., Dale, B., Lohmann, G. P., Smith, W.K., 1977. The environmental and climatic distribution of dinoflagellate cysts in modern marine sediments from regions in the North and South Atlantic Oceans and adjacent seas. Marine Micropaleontology 2, 121-200.

Witkowski, A., Lange-Bertalot, H., Metzeltin, D., 2000. Diatom flora of marine coasts 1. In: Lange-Bertalot, $\mathrm{H}$. (Ed.) Iconographia Diatomologica, vol. 7, A.R.G. Gantner Verlag, pp. 925.

Woodroffe, C.D., Beech, M.R., Gagan, M.K., 2003. Mid-late Holocene El Niño variability in the equatorial Pacific from coral microatolls. Geophysical Research Letters 30, 1358. https://doi.org/10.1029/2002GL015868

Zonneveld, K.A., Marret, F., Versteegh, G.J., Bogus, K., Bonnet, S., Bouimetarhan, I., Crouch, E., et al., 2013. Atlas of modern dinoflagellate cyst distribution based on 2405 data points. Review of Palaeobotany and Palynology 191, 1-197. https://doi.org/10.1016/ j.revpalbo.2012.08.003 